\title{
Evaluation of global fine-resolution precipitation products and their uncertainty quantification in ensemble discharge simulations
}

\author{
W. Qi ${ }^{1,2}$, C. Zhang ${ }^{1}$, G. Fu' ${ }^{2}$, C. Sweetapple ${ }^{2}$, and H. Zhou ${ }^{1}$ \\ ${ }^{1}$ School of Hydraulic Engineering, Dalian University of Technology, Dalian 116024, China \\ ${ }^{2}$ Centre for Water Systems, College of Engineering, Mathematics and Physical Sciences, University of Exeter, \\ North Park Road, Harrison Building, Exeter, EX4 4QF, UK \\ Correspondence to: C. Zhang (czhang@dlut.edu.cn)
}

Received: 9 July 2015 - Published in Hydrol. Earth Syst. Sci. Discuss.: 10 September 2015

Revised: 11 December 2015 - Accepted: 2 February 2016 - Published: 26 February 2016

\begin{abstract}
The applicability of six fine-resolution precipitation products, including precipitation radar, infrared, microwave and gauge-based products, using different precipitation computation recipes, is evaluated using statistical and hydrological methods in northeastern China. In addition, a framework quantifying uncertainty contributions of precipitation products, hydrological models, and their interactions to uncertainties in ensemble discharges is proposed. The investigated precipitation products are Tropical Rainfall Measuring Mission (TRMM) products (TRMM3B42 and TRMM3B42RT), Global Land Data Assimilation System (GLDAS)/Noah, Asian Precipitation - Highly-Resolved Observational Data Integration Towards Evaluation of Water Resources (APHRODITE), Precipitation Estimation from Remotely Sensed Information using Artificial Neural Networks (PERSIANN), and a Global Satellite Mapping of Precipitation (GSMAP-MVK+) product. Two hydrological models of different complexities, i.e. a water and energy budget-based distributed hydrological model and a physically based semi-distributed hydrological model, are employed to investigate the influence of hydrological models on simulated discharges. Results show APHRODITE has high accuracy at a monthly scale compared with other products, and GSMAP-MVK+ shows huge advantage and is better than TRMM3B42 in relative bias (RB), Nash-Sutcliffe coefficient of efficiency (NSE), root mean square error (RMSE), correlation coefficient (CC), false alarm ratio, and critical success index. These findings could be very useful for validation, refinement, and future development of satellite-based products (e.g. NASA Global Precipitation Measurement). Although large uncertainty exists in heavy precipitation, hy-
\end{abstract}

drological models contribute most of the uncertainty in extreme discharges. Interactions between precipitation products and hydrological models can have the similar magnitude of contribution to discharge uncertainty as the hydrological models. A better precipitation product does not guarantee a better discharge simulation because of interactions. It is also found that a good discharge simulation depends on a good coalition of a hydrological model and a precipitation product, suggesting that, although the satellite-based precipitation products are not as accurate as the gauge-based products, they could have better performance in discharge simulations when appropriately combined with hydrological models. This information is revealed for the first time and very beneficial for precipitation product applications.

\section{Introduction}

Knowledge of precipitation plays an important role in the understanding of the water cycle, and thus in the management of water resources (Sellers, 1997; Sorooshian et al., 2005; Wang et al., 2005; Ebert et al., 2007; Buarque et al., 2011; Tapiador et al., 2012; Yong et al., 2012; Gao and Liu, 2013; Peng et al., 2014a, b). However, precipitation data are not available in many regions, particularly mountainous districts and rural areas in developing countries. For example, northeast China, which plays an important role in food production to support the country's population and is also an industrial region with many heavy industries, frequently suffers from drought, posing a threat to regional sustainable development. In such areas, due to insufficient gauge observations, alterna- 
tive precipitation data are required for efficient management of water resources.

In recent years, implementation of gauge-based and remote satellite-based precipitation products has become popular, particularly for ungauged catchments (Artan et al., 2007; Jiang et al., 2012; Li et al., 2013; Müller and Thompson, 2013; Maggioni et al., 2013; Xue et al., 2013; Kneis et al., 2014; Meng et al., 2014; Ochoa et al., 2014). Numerous precipitation products have been developed to estimate rainfall, for example: Tropical Rainfall Measuring Mission (TRMM) products (Huffman et al., 2007), Global Land Data Assimilation System (GLDAS) precipitation products (Kato et al., 2007), Asian Precipitation - Highly-Resolved Observational Data Integration Towards Evaluation of Water Resources (APHRODITE) (Xie et al., 2007; Yatagai et al., 2012), Precipitation Estimation from Remotely Sensed Information using Artificial Neural Networks (PERSIANN) (Sorooshian et al., 2000, 2002), and Global Satellite Mapping of Precipitation product (GSMAP) (Kubota et al., 2007; Aonashi et al., 2009).

There are uncertainties in these products. Several studies have been carried out to analyse the uncertainty of TRMM in high-latitude regions (Yong et al., 2010, 2012, 2014; Chen et al., 2013a; Zhao and Yatagai, 2014), but studies in northeast China are few. Evaluation of GLDAS data has generally been limited to the United States and other observationrich regions of the world (Kato et al., 2007); assessments and applications in other regions are rare (Wang et al., 2011; Zhou et al., 2013). The APHRODITE, PERSIANN, and GSMAP products are seldom evaluated in northeast China using basin-scale gauge data (Zhou et al., 2008). Owing to the high heterogeneity of rainfall across a variety of spatiotemporal scales, the uncertainty characteristics of precipitation products are variable (Asadullah et al., 2008; Dinku et al., 2008; Nikolopoulos et al., 2010; Pan et al., 2010). Thus, in northeast China, it is essential to completely evaluate the applicability of these precipitation products. In addition, it is also worth comparing the performance of different precipitation computation recipes: for example, the artificial neural network function used in PERSIANN, the histogram matching approach used in TRMM3B42, and the cloud motion vectors used in GSMAP-MVK+, because the inter-comparison could reveal the strategies that could be used to obtain more accurate precipitation data.

Researchers have implemented precipitation products in discharge simulations and reported discharge uncertainties (Hong et al., 2006; Pan et al., 2010; Serpetzoglou et al., 2010). Also, many uncertainty analysis approaches have been introduced to quantify the uncertainty (Beven and Binley, 1992; Freer et al., 1996; Kuczera and Parent, 1998; Beven and Freer, 2001b; Peters et al., 2003; Heidari et al., 2006; Kuczera et al., 2006; Tolson and Shoemaker, 2007; Blasone et al., 2008; Vrugt et al., 2009). In these prior approaches, one of the popular methods is the generalized likelihood uncertainty estimation (GLUE) technique, introduced by Beven and Binley (1992). This approach outputs probability distributions of model parameters conditioned on observed data, and the uncertainties in model inputs are represented by uncertain parameters. Similar to GLUE, Hong et al. (2006) proposed a Monte Carlo-based method to quantify uncertainty in hydrological simulations using satellite precipitation data, in which flow simulation uncertainty is represented by ensemble simulation results.

In addition to individual contributions from hydrological models and precipitation data, the interactions between precipitation products and hydrological models also contribute to uncertainty in simulated discharges. However, to the best of our knowledge, the previous studies have not quantified the respective contributions of precipitation products, hydrological models, and their interactions to the total discharge simulation uncertainty.

The overall objectives of this paper are (1) to investigate the applicability of six fine-resolution precipitation products using both statistical and hydrological evaluation methods in a small river basin in northeast China; (2) to propose a framework to quantify the contributions of various uncertainties from precipitation products, hydrological models, and their interactions to uncertainty in simulated discharges. The precipitation products investigated are TRMM3B42, TRMM3B42RT, GLDAS/Noah (GLDAS_Noah025SUBP_3H), APHRODITE, PERSIANN, and GSMAP-MVK+. Two hydrological models of different complexities - a water- and energy-budget-based distributed hydrological model (WEB-DHM) (Wang et al., 2009a, b, c) and a physically based semi-distributed hydrological model TOPMODEL (Beven and Kirkby, 1979) - were employed to investigate the influence of hydrological models on discharge simulations. The respective uncertainties from precipitation products, hydrological models, and the combined uncertainties from the interactions between products and models are quantified using a global sensitivity analysis approach, i.e. the analysis of variance approach (ANOVA). A river basin with a series of 8-year data is used to demonstrate the methodology.

The paper is organized as follows. Section 2 introduces the study region, precipitation products, hydrological models, and the proposed framework. Section 3 presents the statistical evaluation results. Hydrological evaluations and the implementation of the proposed framework are given in Sect. 4. Discussion is given in Sect. 5. Summary and conclusions are presented in Sect. 6.

\section{Materials and methodology}

\subsection{Biliu basin}

Biliu basin $\left(2814 \mathrm{~km}^{2}\right)$, located in the coastal region between the China Bohai Sea and the China Huanghai Sea, covers longitudes 122.29 to $122.92^{\circ} \mathrm{E}$ and latitudes 39.54 to $40.35^{\circ} \mathrm{N}$. 
Table 1. Precipitation products.

\begin{tabular}{llllll}
\hline Product & $\begin{array}{l}\text { Spatial } \\
\text { resolution }\end{array}$ & $\begin{array}{l}\text { Temporal } \\
\text { resolution }\end{array}$ & Areal coverage & Start date & Type \\
\hline TRMM3B42 & $0.25^{\circ}$ & $3 \mathrm{~h}$ & Global $50^{\circ} \mathrm{N}-\mathrm{S}$ & 1 Jan 1998 & PR + IR + MW + gauge + HM \\
TRMM3B42RT & $0.25^{\circ}$ & $3 \mathrm{~h}$ & Global $50^{\circ} \mathrm{N}-\mathrm{S}$ & $1 \mathrm{Mar} 2000$ & $\mathrm{IR}+\mathrm{MW}$ \\
GLDAS/Noah & $0.25^{\circ}$ & $3 \mathrm{~h}$ & Global $90^{\circ} \mathrm{N}-60^{\circ} \mathrm{S}$ & 24 Feb 2000 & IR + MW + gauge \\
GSMAP-MVK+ & $0.1^{\circ}$ & $1 \mathrm{~h}$ & Global $60^{\circ} \mathrm{N}-\mathrm{S}$ & 1 Mar 2000 & IR + MW + CMV \\
PRRSIANN & $0.25^{\circ}$ & $3 \mathrm{~h}$ & Global $60^{\circ} \mathrm{N}-\mathrm{S}$ & 1 Mar 2000 & PR + IR + MW + ANN \\
APHRODITE & $0.25^{\circ}$ & 1 day & $60-150^{\circ} \mathrm{E}$, & $\begin{array}{l}\text { 1 Jan 1961 } \\
\text { to 2007 }\end{array}$ & gauge \\
\hline
\end{tabular}

PR: precipitation radar; IR: infrared estimation; MW: microwave estimation; HM: histogram matching; CMV: cloud motion vectors; ANN: artificial neural network.

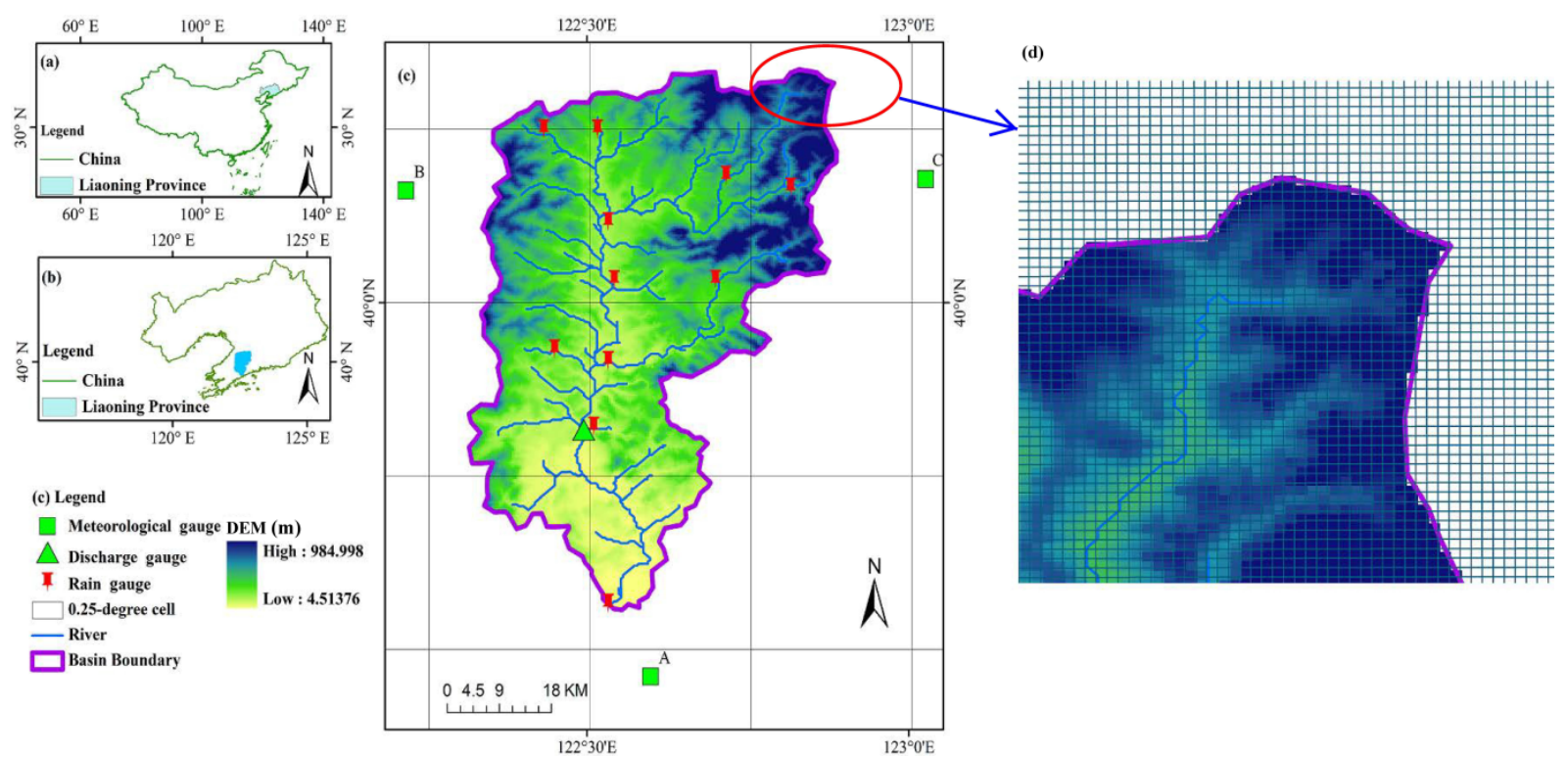

Figure 1. Biliu basin: (a) the location of Liaoning province within China; (b) the location of Biliu basin within Liaoning province; (c) the distributions of rain gauges, discharge gauge, automatic weather stations, digital elevation model, and diagrammatic $0.25^{\circ}$ precipitation cells; and (d) diagrammatic description of downscaling the $0.25^{\circ}$ precipitation cells to $300 \mathrm{~m} \times 300 \mathrm{~m}$ cells, and retrieving the $300 \mathrm{~m} \times 300 \mathrm{~m}$ cells located within the basin boundary.

This basin is characterized by a snow, winter dry, and hot summer climate (Koppen climate classification) and the average annual temperature is $10.6^{\circ} \mathrm{C}$. Summer (July to September) is the major rainy season. There are 11 rainfall stations and one discharge gauge which have historical data from January 2000 to December 2007. The average elevation is $240 \mathrm{~m}$. The gauge distribution in Biliu is shown in Fig. 1. The basin slopes vary from 0 to $38^{\circ}$. Land-use data are obtained from the USGS (http://edc2.usgs.gov/glcc/glcc.php). The land-use types have been reclassified to SiB2 land-use types for this study (Sellers et al., 1996). There are six landuse types, with broadleaf and needle leaf trees and short vegetation being the main types. Soil data are obtained from the Food and Agriculture Organization (FAO, 2003) Global data product, and there are two types of soil in the basin: clay loam Luvisols and loam Phaeozems.

\subsection{Precipitation products}

The selected precipitation products are shown in Table 1 . These data are all freely available. In these selected precipitation products, APHRODITE is wholly based on gauge data; TRMM3B42 and GLDAS are remote satellite estimations with gauge data corrections; while others are remote satellite estimations without gauge data corrections. Remotebased precipitation estimation has many weaknesses; e.g. microwave estimation could miss convective rainfall and typhoon rain because of its sparse time interval resolution; infrared estimation has a higher time interval resolution, but it cannot penetrate thick clouds. Ground rain-gauge-based interpolation products are limited by interpolation algorithms, gauge density, and gauge data quality (Xie et al., 2007). The details of data sources used in each precipitation product can 
be found in Table 1. The detailed introductions of these products are as follows.

TRMM is a joint mission between NASA and Japan Aerospace Exploration Agency designed to monitor and study tropical rainfall (Kummerow et al., 2000; Huffman et al., 2007). Three instruments - a visible infrared radiometer, a TRMM microwave imager, and a precipitation radar are employed to obtain accurate precipitation estimation. The TRMM precipitation radar is the first space-based precipitation radar and operates between $35^{\circ} \mathrm{N}$ and $35^{\circ} \mathrm{S}$. Outside this band, the microwave imager is used between $40^{\circ} \mathrm{N}$ and $40^{\circ} \mathrm{S}$, and the visible infrared radiometer data are used between $50^{\circ} \mathrm{N}$ to $50^{\circ} \mathrm{S}$. Usually the precipitation radar is considered to give the most accurate estimation from satellite, and data from it are often used for calibration of passive microwave data from other instruments (Ebert et al., 2007). The post-real-time product used in this study is the TRMM3B42, which utilizes three data sources: the TRMM combined instrument estimation using data from both TRMM precipitation radar and the microwave imager; the GPCP monthly rain gauge analysis developed by the Global Precipitation Climatology Center; and the Climate Assessment and Monitoring System monthly rain gauge analysis. TRMM3B42 applies an infrared to rain rate relationship using histogram matching, while TRMM3B42RT merges microwave and infrared precipitation estimation.

PERSIANN is a product that, using an artificial neural network function, estimates precipitation by combining infrared precipitation estimation and the TRMM combined instrument estimation (which assimilates with TRMM precipitation radar and microwave data). GSMAP-MVK+ uses microwave and infrared precipitation data together and combines cloud motion vectors to generate fine-resolution precipitation estimation.

The Global Land Data Assimilation System (GLDAS) project is an extension of the existing and more mature North American Land Data Assimilation System (Rodell et al., 2004). It integrates satellite- and ground-based data sets for parameterizing, forcing, and constraining a few offline land surface models for generating optimal fields of land surface states and fluxes. At present, GLDAS drives four land surface models: Mosaic (Koster and Suarez, 1992), Noah (Chen et al., 1996; Betts et al., 1997; Koren et al., 1999; Ek, 2003), the Community Land Model (Dai et al., 2003), and the Variable Infiltration Capacity model (Liang et al., 1994). Among them, the GLDAS/Noah Land Surface Model product (GLDAS_NOAH025SUBP_3H) has a $3 \mathrm{~h} 0.25^{\circ} \times 0.25^{\circ}$ resolution, which is desirable for basin-scale research. The GLDAS precipitation data combine microwave and infrared data, and also assimilate gauge observations.

\subsection{Criteria for accuracy assessment}

Uncertainties of precipitation products are evaluated on the basis of basin-averaged rainfall observations. Four evalua- tion criteria are used in rainfall amount error assessment: correlation coefficient (CC), root mean square error (RMSE), Nash-Sutcliffe coefficient of efficiency (NSE), and relative bias (RB). These are calculated as follows:

$$
\begin{aligned}
& \mathrm{RMSE}=\left(\frac{\sum_{i=1}^{n}\left(X_{p i}-X_{o i}\right)^{2}}{n}\right)^{\frac{1}{2}} \\
& \mathrm{NSE}=1-\frac{\sum_{i=1}^{n}\left(X_{p i}-X_{o i}\right)^{2}}{\sum_{i=1}^{n}\left(X_{p i}-\overline{X_{o}}\right)^{2}} \\
& \mathrm{RB}=\frac{\sum_{i=1}^{n} X_{p i}-\sum_{i=1}^{n} X_{o i}}{\sum_{i=1}^{n} X_{o i}} \times 100 \%,
\end{aligned}
$$

where $X_{o i}$ represents observed data; $X_{p i}$ represents estimated data; $n$ is the total number of data points. A perfect fit should have CC and NSE values of 1 . The lower the RMSE and RB, the better the estimation. These comparison criteria have been used by many studies (Ebert et al., 2007; Wang et al., 2011; Yong et al., 2012), so they are used in this study.

Probability distributions by occurrence and volume are also analysed, which can provide us with the information on the frequency and on the product error dependence on precipitation intensity (Chen et al., 2013a, b). The critical success index (CSI), probability of detection (POD), and false alarm ratio (FAR) are used to quantify the ability of precipitation products to detect observed rainfall events. These are defined as follows:

$$
\begin{aligned}
\mathrm{CSI} & =\frac{H}{H+M+F} \\
\mathrm{POD} & =\frac{H}{H+M} \\
\mathrm{FAR} & =\frac{F}{H+F},
\end{aligned}
$$

where $H$ is the total number of hits; $M$ is the total number of misses; $F$ is the total number of false alarms (Ebert et al., 2007; Su et al., 2008). A perfect detection should have CSI and POD values equal to 1 and a FAR value of 0 .

\subsection{Hydrological models and data}

\subsubsection{WEB-DHM}

The distributed biosphere hydrological model, WEB-DHM (Wang et al., 2009a, b, c), was developed by coupling a simple biosphere scheme (Sellers et al., 1986) with a geomorphology-based hydrological model (Yang, 1998) to describe water, energy, and $\mathrm{CO}_{2}$ fluxes at a basin scale. 
WEB-DHM has been used in several evaluations and applications (Wang et al., 2010a, b, 2012; Shrestha et al., 2014).

WEB-DHM input data include precipitation, temperature, downward solar radiation, long-wave radiation, air pressure, wind speed, and humidity. With the exception of precipitation, all input data are obtained from automatic weather stations. There are three automatic weather stations near Biliu, and observations from these are obtained from the China Meteorological Data Sharing Service System (downloaded from http://cdc.cma.gov.cn/home.do). Hourly precipitation data are downscaled from daily rain gauge observations using a stochastic method (Wang et al., 2011). Hourly temperatures are calculated from daily maximum and minimum temperatures using a temperature model (Parton and Logan, 1981). The estimated temperatures are also further evaluated using daily average temperature. Downward solar radiation is estimated from sunshine duration, temperature, and humidity using a hybrid model (Yang et al., 2006). Longwave radiation is obtained from the GLDAS/Noah (Rodell et al., 2004). Air pressure is estimated according to altitude (Yang et al., 2006). These meteorological data are then interpolated to $300 \mathrm{~m} \times 300 \mathrm{~m}$ model cells through an inversedistance weighting approach. Because of the elevation differences among model cells and meteorological gauges, the interpolated surface air temperatures are further modified with a lapse rate of $6.5 \mathrm{~K} \mathrm{~km}^{-1}$. Gauge rainfall data are also interpolated to $300 \mathrm{~m} \times 300 \mathrm{~m}$ model cells and basin-averaged gauge rainfall data are calculated on the basis of interpolation results. In addition to the above, the leaf area index and fraction of photosynthetically active radiation data are obtained from level-4 MODIS global product MOD11A2. The digital elevation model (DEM) is from the NASA SRTM (Shuttle Radar Topographic Mission) with a resolution of $30 \mathrm{~m} \times 30 \mathrm{~m}$. We resampled the resolution to $300 \mathrm{~m}$ in model calculation to reduce computation cost, while the model processed finer DEMs (30 m grid) to generate sub-grid parameters (such as hillslope angle and length).

\subsubsection{TOPMODEL}

TOPMODEL is a physically based, variable-contributing area model of basin hydrology which attempts to combine the advantages of a simple lumped parameter model with distributed effects (Beven and Kirkby, 1979). Fundamental to TOPMODEL's parameterization are three assumptions: (1) saturated-zone dynamics can be approximated by successive steady-state representations; (2) hydrological gradients of the saturated zone can be approximated by the local topographic surface slope; and (3) the transmissivity profile whose form declines exponentially with increasing vertical depth of the water table or storage is spatially constant. On the basis of the above-mentioned assumptions, the index of hydrological similarity is represented as the topographic in$\operatorname{dex}, \ln (a / \tan \beta)$, for which $a$ is the area per unit contour length and $\beta$ is the local slope angle. More detailed descrip-

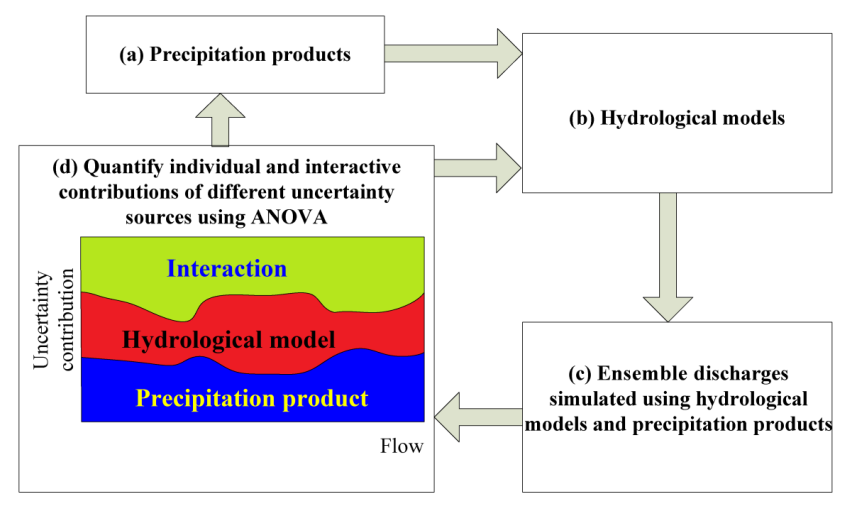

Figure 2. Diagrammatic flowchart of the proposed framework for quantification of uncertainty contributions to ensemble discharges simulated using precipitation products on the basis of the analysis of variance (ANOVA) approach.

tions of TOPMODEL and its mathematical formulation can be found in Beven and Kirkby (1979). TOPMODEL has been popularly utilized in research across the world (Blazkova and Beven, 1997; Cameron et al., 1999; Hossain and Anagnostou, 2005; Bastola et al., 2008; Gallart et al., 2008; Bouilloud et al., 2010; Qi et al., 2013), because of its relatively simple model structure. The input data of TOPMODEL mainly include basin-averaged precipitation and topographic data which can be estimated from DEM.

\subsection{The proposed framework}

Figure 2 shows the diagrammatic flowchart of the proposed framework for quantification of uncertainty contributions to ensemble discharges simulated using precipitation products. This framework includes four parts: (a) selection of precipitation products; (b) selection of hydrological models; (c) ensemble of discharge simulations using the hydrological models and precipitation products; and (d) quantification of individual and interactive contributions using the analysis of variance (ANOVA) approach including contributions from precipitation products, hydrological models, and interactions between models and products. Because the spatial resolution of selected precipitation products does not correspond with WEB-DHM model cells, the following procedures were carried out for basin-averaged rainfall calculations: (1) resampling 0.25 or $0.1^{\circ}$ precipitation product grids into $300 \mathrm{~m} \times 300 \mathrm{~m}$ cells (the grid size used in WEBDHM simulations); (2) calculating basin-averaged precipitation using $300 \mathrm{~m}$ precipitation product grids located within the basin boundary. Diagrammatic descriptions of these procedures are shown in Fig. 1d. Because WEB-DHM needs hourly input data, for the $3 \mathrm{~h}$ resolution precipitation products, we assumed rainfall is uniformly distributed within each $3 \mathrm{~h}$ period. For daily resolution products, we used the same approach as downscaling observed precipitation data. This downscaling approach may affect uncertainty in simulated 
discharge. However, Wang et al. (2011) have already successfully applied the downscaling approach, and shown that the influence is negligible.

The total ensemble uncertainty $Y$ is the variance of discharges. To relate $Y$ to the uncertainty sources, the superscripts $j$ and $k$ in $Y^{j, k}$ represent a combination of precipitation product $j$ and hydrological model $k$ :

$Y^{j, k}=P^{j}+M^{k}+P M^{j, k}$,

where $P$ represents the effect of $j$ th precipitation product, $M$ represents the effect of $k$ th hydrological model, and $P M$ represents the interaction effect. In this study, $j$ varies from one to six, and $k$ varies from one to two. Details of the quantification are explained in the follow sections.

\subsubsection{Subsampling approach}

ANOVA could underestimate variance when the sample size is small (Bosshard et al., 2013). To reduce the effect of the sample size, Bosshard et al. (2013) proposed a subsampling method, which was used in this paper. In the subsampling method, the superscript $j$ in Eq. (7) is replaced with $\mathbf{g}(h, i)$. According to Bosshard et al. (2013), in each subsampling iteration $i$, data from two products should be selected out of all the six products, and thus 15 combinations can be obtained. Therefore, the superscript $\mathbf{g}$ becomes a $2 \times 15$ matrix:

$\mathbf{g}=\left(\begin{array}{cccccccccc}1 & 1 & \ldots & 1 & 2 & 2 & \ldots & 4 & 4 & 5 \\ 2 & 3 & \ldots & 6 & 3 & 4 & \ldots & 5 & 6 & 6\end{array}\right)$.

\subsubsection{Uncertainty contribution decomposition}

Based on the ANOVA theory (Bosshard et al., 2013), total error variance (SST) can be divided into sums of squares due to the individual effects as

$\mathrm{SST}=\mathrm{SSA}+\mathrm{SSB}+\mathrm{SSI}$,

where SSA is the error contribution of precipitation products, SSB is the error contribution of hydrological models, and SSI is the error contribution of their interactions.

The terms can be estimated using the subsampling procedure as follows:

$\operatorname{SST}_{i}=\sum_{h=1}^{H} \sum_{k=1}^{K}\left(Y^{g(h, i), k}-Y^{g(o, i), o}\right)^{2}$

$\mathrm{SSA}_{i}=K \cdot \sum_{h=1}^{H}\left(Y^{g(h, i), o-} Y^{g(o, i), o}\right)^{2}$

$\operatorname{SSB}_{i}=H \cdot \sum_{k=1}^{K}\left(Y^{g(o, i), k}-Y^{g(o, i), o}\right)^{2}$

$\mathrm{SSI}_{i}=\sum_{h=1}^{H} \sum_{k=1}^{K}\left(Y^{g(h, i), k}-Y^{g(h, i), o}-Y^{g(o, i), k}+Y^{g(o, i), o}\right)^{2}$,

where symbol ${ }^{o}$ indicates averaging over a particular index; $H$ is the number of precipitation products (six in this study) and $K$ is the number of hydrological models (two in this study). Then the variation fraction $\eta^{2}$ is calculated as follows:

$$
\begin{aligned}
& \eta_{\text {precipitation }}^{2}=\frac{1}{I} \sum_{i=1}^{I} \frac{\mathrm{SSA}_{i}}{\mathrm{SST}_{i}} \\
& \eta_{\text {model }}^{2}=\frac{1}{I} \sum_{i=1}^{I} \frac{\mathrm{SSB}_{i}}{\mathrm{SST}_{i}} \\
& \eta_{\text {interaction }}^{2}=\frac{1}{I} \sum_{i=1}^{I} \frac{\mathrm{SSI}_{i}}{\mathrm{SST}_{i}}
\end{aligned}
$$

$\eta^{2}$ has a value between 0 and 1 , which represent 0 and $100 \%$ contributions to the overall uncertainty of simulated discharges respectively. $I$ equals 15 in this study. As shown in Eqs. (14)-(16), the subsampling approach is necessary because it guarantees that every contributor has the same denominator $I$. This same denominator makes sure that the inter-comparison among precipitation contribution, model contribution, and interaction contribution is free of influence from the sampling number of precipitation products and hydrological models.

\section{Statistical evaluations}

\subsection{Daily and monthly scales}

Comparison of precipitation product data and gauge observations at a daily scale is shown in Fig. 3. Observations are shown on the $x$ axis and precipitation product data are shown on the $y$ axis. Four criteria, RMSE, CC, NSE, and $\mathrm{RB}$, are also shown. GSMAP-MVK+ is the best product and PERSIANN has the poorest performance with respect to RMSE and NSE. GSMAP-MVK+ is also the best with respect to CC, while GLDAS has the poorest performance with a $C C$ value of 0.55 . With respect to RB, APHRODITE performs best and GSMAP-MVK + the second best, while TRMM3B42RT the least best with an RB value of $-38 \%$. None of the products can outperform others in terms of all the statistical criteria. This may be due to the different limitations of satellite sensors and inverse algorithms of precipitation products. This situation shows that the selection of the best precipitation products is difficult.

TRMM3B42RT and TRMM3B42 underestimate precipitation amounts. This underestimation may be because convective rainfall always happens in summer in northeast China (Shou and Xu, 2007a, b; Yuan et al., 2010), and indicates the limitation of TRMM algorithms in high-latitude regions with convective rainfall. This type of rainfall has a large rainfall amount within a short time period and, therefore, cannot be captured by microwave imager. This type of rainfall may also have a thick cloud that is impenetrable by infrared (Ebert et al., 2007). Thus microwave and infrared estimation could underestimate rainfall. Compared with 

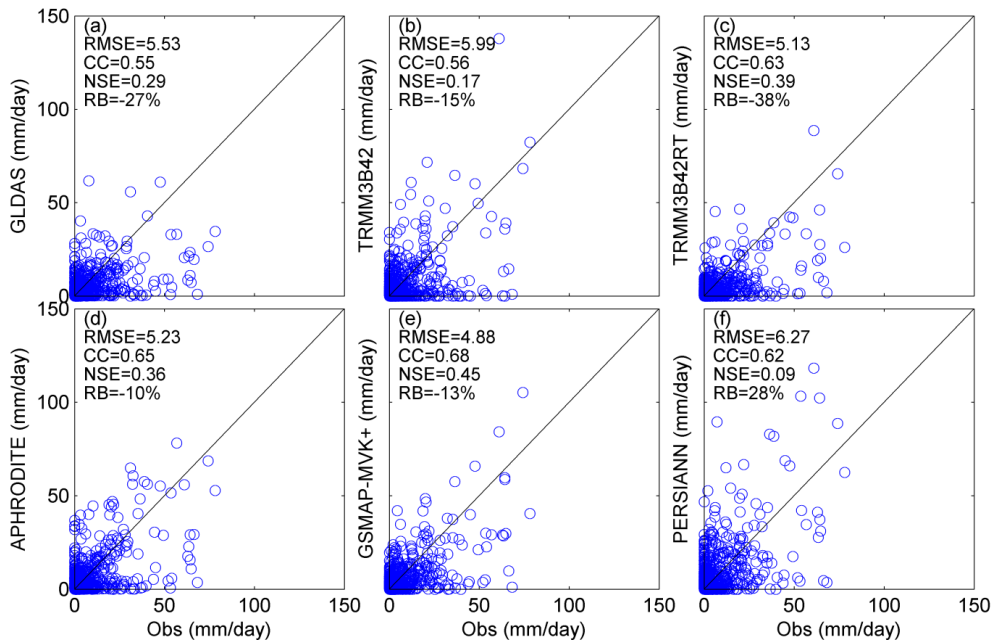

Figure 3. Scatter plots of basin-averaged precipitation products versus gauge observations at a daily scale.
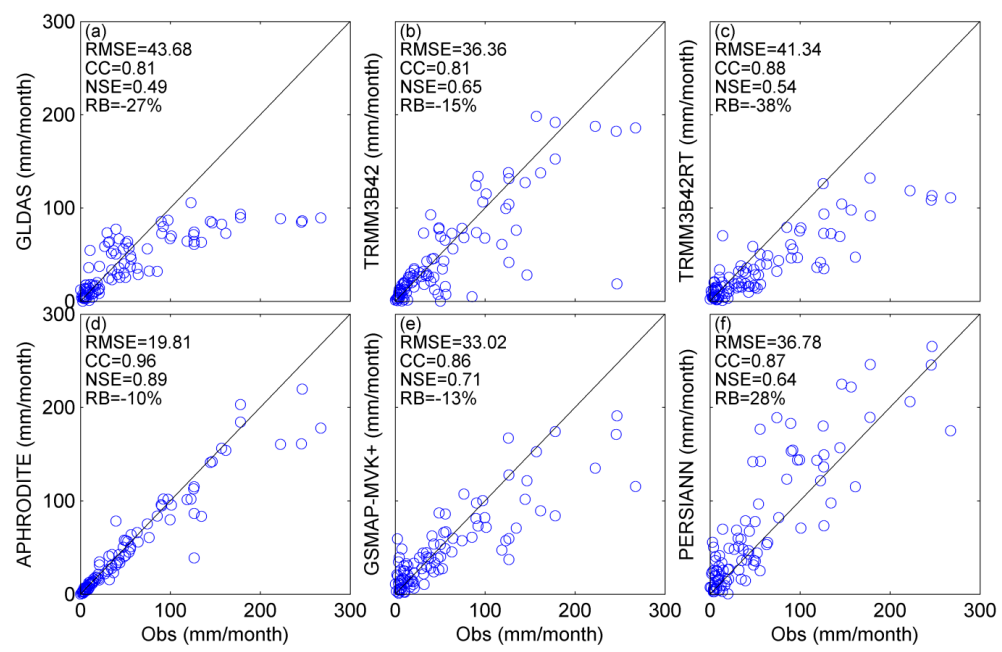

Figure 4. Scatter plots of basin-averaged precipitation products versus gauge observations at a monthly scale.

TRMM3B42RT, TRMM3B42 provides an improvement in RB. This improvement may be attributed to the assimilation with gauge data and histogram matching. Compared with APHRODITE and GSMAP-MVK+, TRMM3B42 has low accuracy as represented by RB. This implies that the retrieval algorithm used by TRMM3B42 still needs to be improved with respect to $\mathrm{RB}$. The reason why APHRODITE outperforms TRMM3B42 is that APHRODITE is a gaugebased product. The fact that GSMAP-MVK+ outperforms TRMM3B42 in terms of RB may be due to the cloud motion vectors it uses. Compared with GSMAP-MVK+, GLDAS/Noah precipitation shows low accuracy in all the criteria even though they use similar data sources: IR and MW.

Comparison of precipitation product data and gauge observations at a monthly scale is shown in Fig. 4. Here, the APHRODITE product (Fig. 4d) performs best based on
RMSE, CC, NSE, and RB. GLDAS/Noah is the poorest in terms of RMSE and NSE. With respect to CC, GLDAS and TRMM3B42 are equally poor, with CC values of 0.81 . The results also show that PERSIANN overestimates precipitation amount, while Li et al. (2013) found PERSIANN underestimates rainfall in south China. This may be attributed to the different latitudes of the study regions.

Figure 5 shows time series of average monthly precipitation data against gauge observations during the period 2000 2007. Each curve represents a different precipitation product. GLDAS data (Fig. 5a) seriously underestimate high rainfall. Similarly, TRMM3B42RT underestimates peak precipitation intensity also. Comparatively, APHRODITE, PERSIANN, TRMM3B42, and GSMAP-MVK+ have better performances. 

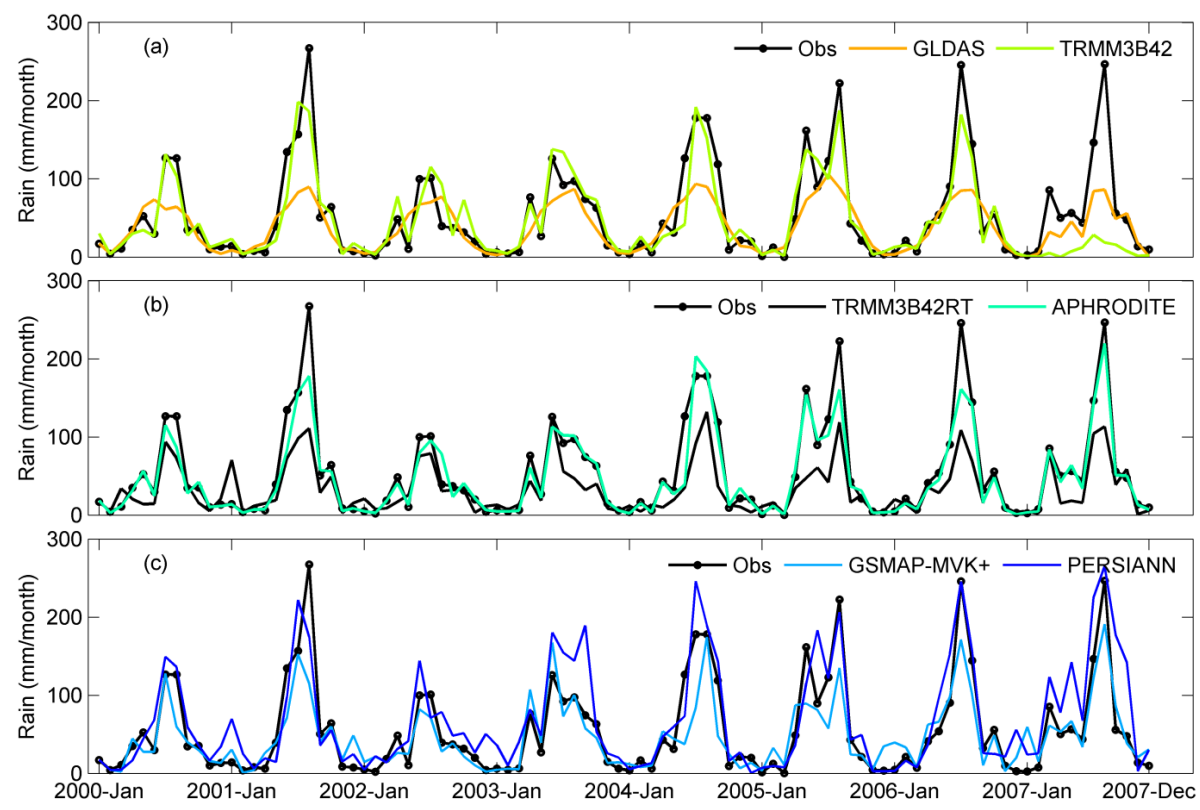

Figure 5. Time series plots of basin-averaged precipitation product values versus gauge observations at a monthly scale.

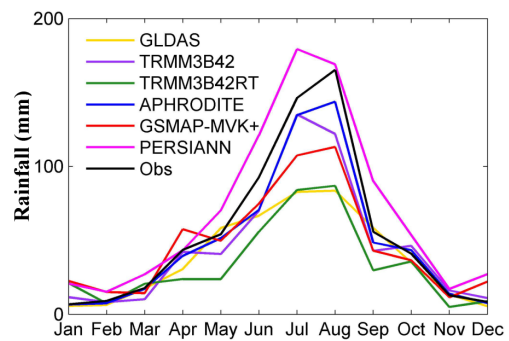

Figure 6. Inter-annual basin-averaged monthly precipitation.

\subsection{Inter-annual evaluations}

Figure 6 shows the inter-annual average monthly precipitation. Each curve represents a different data product. PERSIANN overestimates in all the 12 months, while others underestimate, especially during the summer. This may result from the artificial neural network function and limitations of infrared and microwave estimation. APHRODITE data are relatively close to observations. Compared with TRMM3B42RT, TRMM3B42 is better, which indicates that the gauge corrections and histogram-matching used by TRMM3B42 impact positively on accuracy. During the summer, discrepancies between products become larger. With a decrease of rainfall magnitude, the discrepancies between products reduce. This information implies that the differences in precipitation estimation are related to precipitation magnitudes: the larger the rainfall magnitudes, the greater the differences.
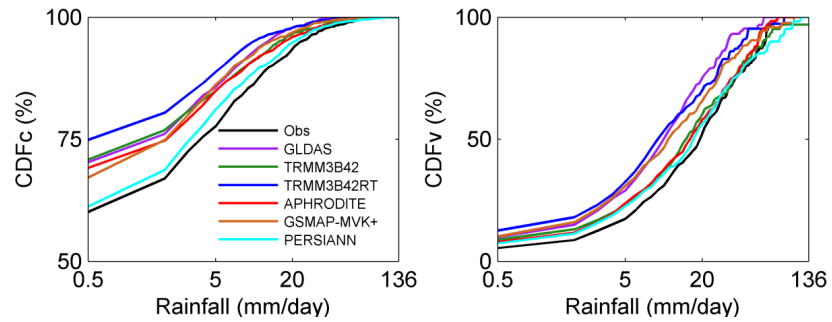

Figure 7. Probability distributions of the six precipitation products by occurrence $(\mathrm{CDFc})$ and volume $(\mathrm{CDFv})$.

\subsection{Probability distribution evaluations}

Figure 7 shows the cumulative probability distribution function $(\mathrm{CDF})$ by occurrence $(\mathrm{CDFc})$ and by volume $(\mathrm{CDFv})$ for precipitation products. Probabilities are shown on the $y$ axis, and the $x$ axis shows rainfall intensity with a $1 \mathrm{~mm} \mathrm{day}^{-1}$ interval log space.

PERSIANN is the best by both occurrence and volume. However, for CDFc, TRMM3B42RT is the least best, and, for CDFv, TRMM3B42RT, and GLDAS/Noah are comparable and worse than others. All precipitation products overestimate occurrence and volume probabilities except rainfall intensities of larger than 63 and $53 \mathrm{~mm} \mathrm{day}^{-1}$ for occurrence and volume probabilities, respectively. This may be because the precipitation products overestimate the intensity of some heavy rainfall (recall the results in Sect. 3.1). The results differ from those of Li et al. (2013), in which PERSIANN has the poorest performance. This may result from differences in study region (in the study of Li et al. (2013), south China was studied). 

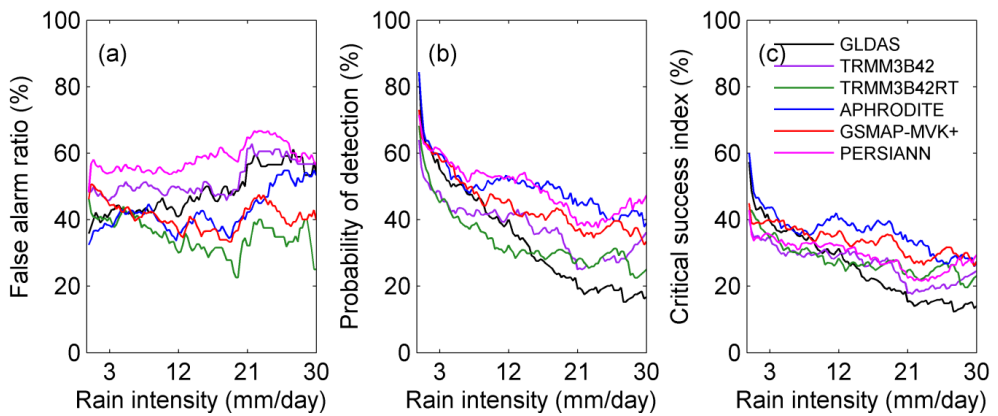

Figure 8. False alarm ratio, probability of detection, and critical success index for the six precipitation products.

\subsection{Contingency statistics}

Figure 8 shows the false alarm ratio, probability of detection, and critical success index for each precipitation product.

PERSIANN has the highest false alarm ratio among the products, while TRMM3B42RT has the lowest. The false alarm ratio of TRMM3B42 is larger than TRMM3B42RT, which indicates that the gauge corrections and histogrammatching used by TRMM3B42 do not provide positive effects on false alarm ratio and may give rise to uncertainty in false alarm ratio. GSMAP-MVK+ has a lower false alarm ratio than TRMM3B42.

No obvious trends are observed for the false alarm ratio overall (compared with the probability of detection and critical success index), which means the false alarm ratio dependence on rainfall magnitude is weak. However, Chen et al. (2013a) found the false alarm ratios of TRMM3B42 and TRMM3B42RT to increase with an increase in rainfall intensity. The differences are attributed mainly to observed data. In the study of Chen et al. (2013a), national rain gauge data were employed, whereas in this study more detailed basin data are used.

Among all selected products, GLDAS/Noah has the lowest probability of detection and critical success index during periods of high rainfall intensity, while APHRODITE retains a high probability of detection and critical success index. This is because APHRODITE uses gauge observations, and implies that the APHRODITE algorithm is effective. PERSIANN has comparable probability of detection with APHRODITE. The critical success index of GSMAPMVK+ is also comparable with APHRODITE. Compared with TRMM3B42RT, TRMM3B42 has greater probability of detection and comparable critical success index. This information implies that the retrieval algorithm of TRMM3B42 provides positive effects on probability of detection, but no obvious positive impacts on critical success index.

Decreasing trends are observed for all products in terms of probability of detection and critical success index, matching the results of Chen et al. (2013a) for TRMM3B42 and TRMM3B42RT. This indicates that probability of detection and critical success index have relatively strong dependence on rainfall magnitude, and implies that microwave and infrared precipitation estimation may have relatively strong dependence on rainfall magnitude in terms of probability of detection and critical success index.

\section{Hydrological evaluations}

\subsection{Assessment of hydrological models}

WEB-DHM was calibrated against observed discharges of Biliu. Six main parameters were selected to calibrate using a trial and error approach due to the model's computational burden. Model parameter multipliers were calibrated, similar to the study by Wang et al. (2011). The trial and error approach has two steps. First, all the multiplier values are set to 1 which represents the default parameter values from the Food and Agriculture Organization (FAO, 2003) and the $\mathrm{SiB} 2$ model. Second, the multiplier values are varied until acceptable discharge simulation accuracy is obtained. The calibrated parameter values are listed in Table 2 . The simulated daily, monthly, and inter-annual results are shown in Fig. 9a, c, and e.

TOPMODEL uses basin-averaged parameter values, and these parameter values are estimated by experience or observation. However, these methods do not give precise parameter values. Therefore, the parameter values are considered as uncertain and provided with ranges based on experience (Beven and Kirkby, 1979; Beven and Freer, 2001a, b; Peters et al., 2003). Six parameters of TOPMODEL were calibrated using the dynamically dimensioned search algorithm (Tolson and Shoemaker, 2007), and the results are given in Table 3 . The simulated daily, monthly, and inter-annual results are shown in Fig. 9b, d, and f.

Note that the parameters of TOPMODEL and WEB-DHM were calibrated using observed precipitation data, and the accuracy of simulated discharges was validated using gauge observations. Comparison with the rainfall-runoff model parameter values reported for the case study catchment in previous research shows that the parameter values are appropriate (Qi et al., 2013, 2015, 2016). 
Table 2. WEB-DHM parameters.

\begin{tabular}{llr}
\hline Symbol (unit) & Brief description & $\begin{array}{r}\text { Basin-averaged } \\
\text { value }\end{array}$ \\
\hline$K_{\mathrm{S}}\left(\mathrm{mm} \mathrm{h}^{-1}\right)$ & Saturated hydraulic conductivity for soil surface & 26.43 \\
Anik & Hydraulic conductivity anisotropy ratio & 11.49 \\
$\mathrm{Sst}_{\max }(\mathrm{mm})$ & Maximum surface water storage & 42.75 \\
$K_{\mathrm{g}}\left(\mathrm{mm} \mathrm{h}^{-1}\right)$ & Hydraulic conductivity for groundwater & 0.36 \\
$\alpha$ & van Genuchten parameter & 0.01 \\
$n$ & van Genuchten parameter & 1.88 \\
\hline
\end{tabular}
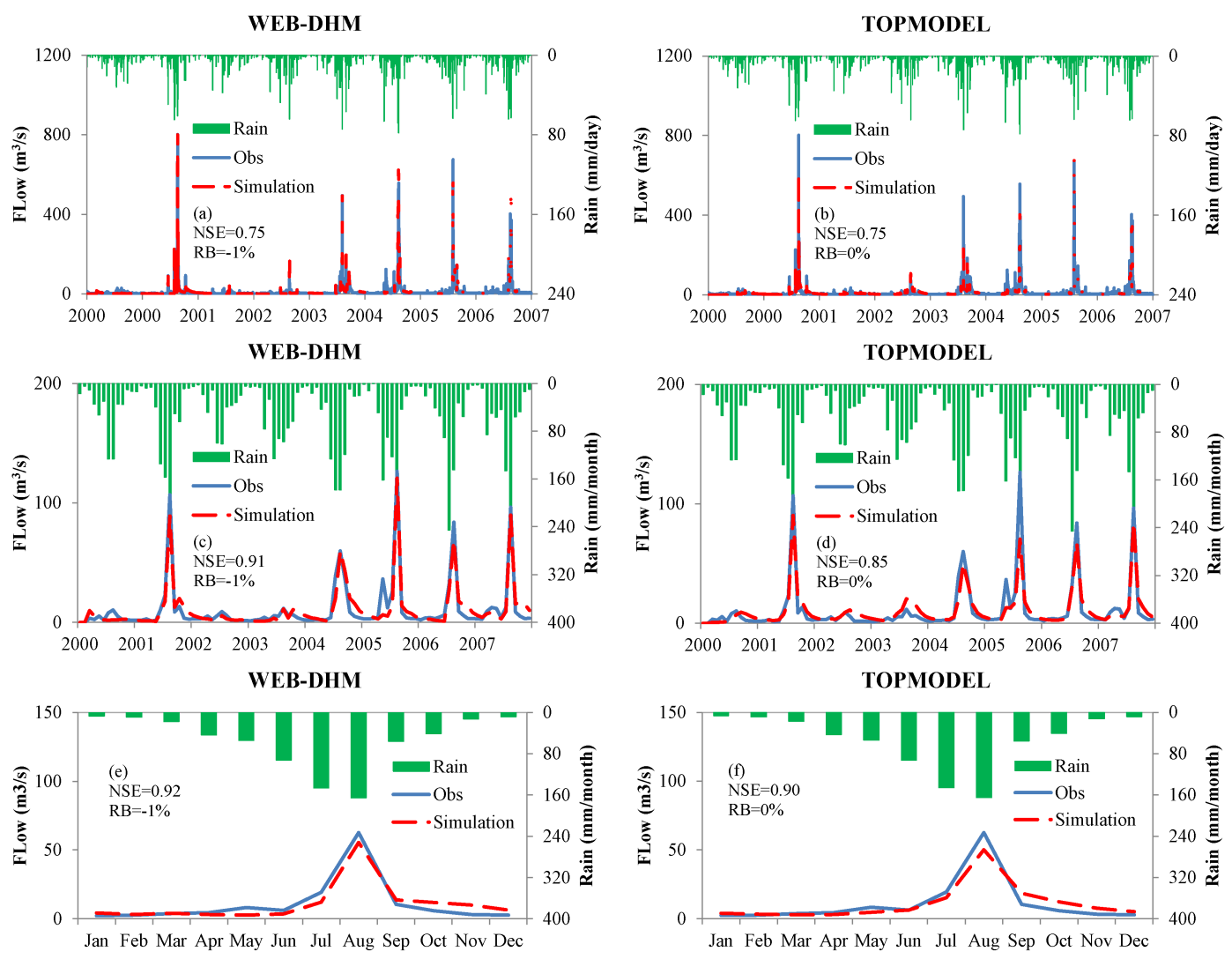

Figure 9. Observed and simulated flows using WEB-DHM and TOPMODEL from 2000 to 2007: (a), (c), and (e) are daily, monthly, and inter-annual simulations using WEB-DHM respectively; (b), (d), and (f) are daily, monthly, and inter-annual simulations using TOPMODEL respectively.

\subsection{Daily-scale discharges}

Figures 10 and 11 display scatter plots of discharges during the period 2000-2007 simulated using WEB-DHM and TOPMODEL against gauge observations at a daily scale. Two criteria, NSE and RB, are shown. It should been noted that the start dates are different for precipitation products, and observed data were used when product data are not available: from 1 January 2000 to 29 February 2000 for TRMM3B42RT, GSMAP-MVK+, and PERSIANN; from 1 January 2000 to 23 February 2000 for GLDAS/Noah.
These time periods were not considered for accuracy comparison.

In the case of WEB-DHM simulations, the best NSE (0.41) corresponds with APHRODITE (Fig. 10d), while the best value for RB (1\%) corresponds with GLDAS/Noah. In the case of TOPMODEL simulations, the best NSE (0.41) corresponds with APHRODITE, and the best value for RB $(-24 \%)$ corresponds with APHRODITE also. Although the best NSE is the same for both WEB-DHM and TOPMODEL simulations and the corresponding product is also the same, there is a large difference in the best $R B$ values. At the daily-scale precipitation amount evaluation, the least best 
Table 3. TOPMODEL parameters.

\begin{tabular}{lllll}
\hline Name (unit) & Description & $\begin{array}{l}\text { Lower } \\
\text { bound }\end{array}$ & $\begin{array}{l}\text { Upper } \\
\text { bound }\end{array}$ & Calibration \\
\hline $\mathrm{SZM}(\mathrm{m})$ & $\begin{array}{l}\text { form of the exponential } \\
\text { decline in conductivity }\end{array}$ & 0.01 & 0.04 & 0.019 \\
\hline $\mathrm{LNT0}\left(\mathrm{m}^{2} \mathrm{~h}^{-1}\right)$ & $\begin{array}{l}\text { log value of effective } \\
\text { lateral saturated } \\
\text { transmissivity }\end{array}$ & -25 & 1 & -11.911 \\
\hline $\mathrm{RV}\left(\mathrm{m} \mathrm{h}^{-1}\right)$ & $\begin{array}{l}\text { hill slope routing } \\
\text { velocity }\end{array}$ & 2000 & 5000 & 2608.4 \\
\hline $\mathrm{SR} \mathrm{max}_{(\mathrm{m})}$ & $\begin{array}{l}\text { maximum root zone } \\
\text { storage }\end{array}$ & 0.001 & 0.01 & 0.006 \\
\hline $\mathrm{SR}(\mathrm{m})$ & initial root zone deficit & 0 & 0.01 & 0.005 \\
\hline $\mathrm{TD}\left(\mathrm{m} \mathrm{h}^{-1}\right)$ & $\begin{array}{l}\text { unsaturated zone time } \\
\text { delay per unit deficit }\end{array}$ & 2 & 4 & 2.885 \\
\hline
\end{tabular}
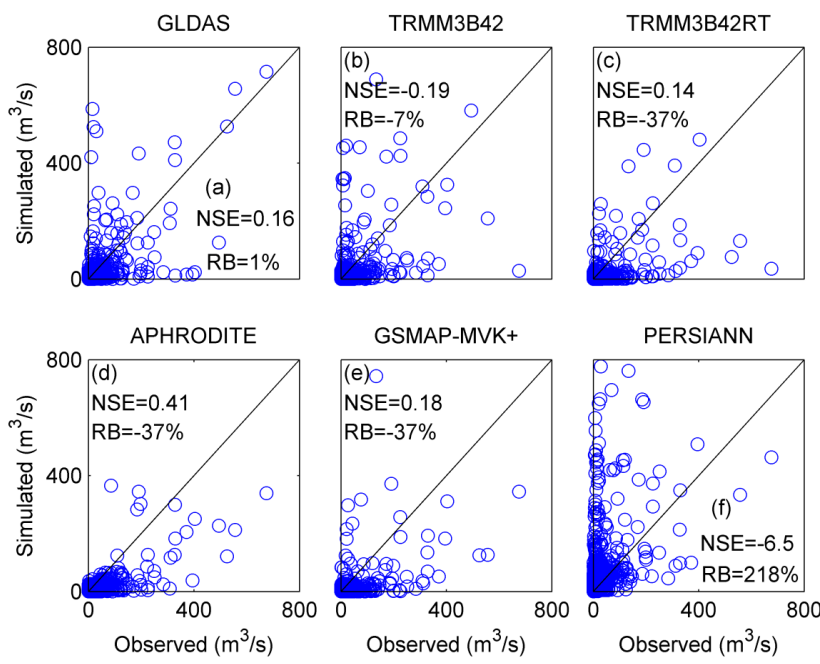

Figure 10. Scatter plots of simulated discharges with WEB-DHM against gauge observations at a daily scale.

RB is $-38 \%$, corresponding with TRMM3B42RT (Fig. 3c). However, in WEB-DHM discharge simulation, the least best RB $(218 \%)$ corresponds with PERSIANN, and, in the TOPMODEL simulation, the least best RB $(-62 \%)$ corresponds with TRMM3B42RT. These differences stem from differences in hydrological models and interactions between hydrological models and precipitation product data.

All RB criteria at the daily-scale precipitation evaluations (recall the results in Fig. 3) are amplified by TOPMODEL, while in the case of WBE-DHM, some are amplified and the others are decreased. For example, for GLDAS and PERSIANN, the RB criteria at the daily-scale precipitation evaluations are -27 and $28 \%$, but they are -50 and $31 \%$ in TOPMODEL simulations; they are 1 and $218 \%$ in WEB-DHM
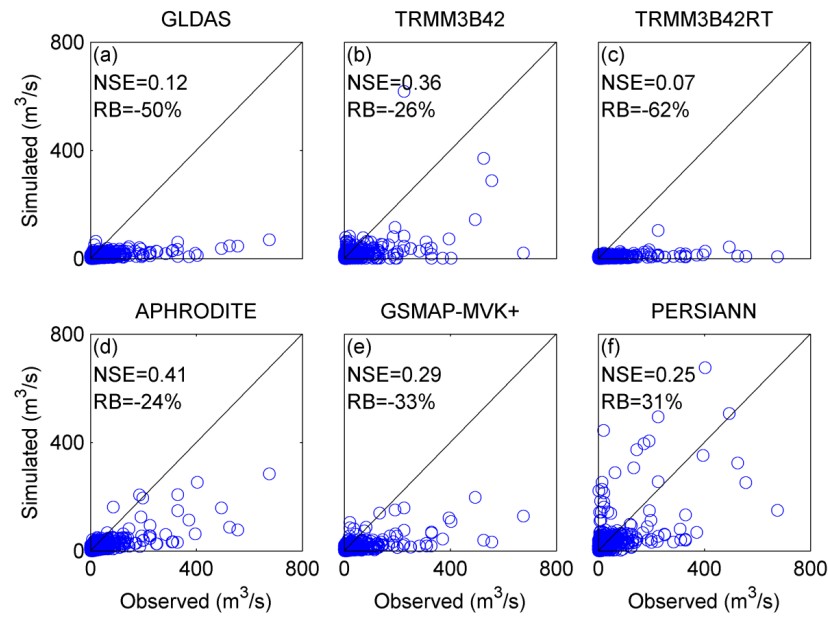

Figure 11. Scatter plots of simulated discharges with TOPMODEL against gauge observations at a daily scale.

simulations. These differences result from the influence of hydrological models and interactions between precipitation products and hydrological models. These results reveal that a hydrological model can amplify uncertainties in input data but also reduce uncertainties, which may be due to the nonlinear runoff generation process in hydrological models. This finding is consistent with the research by Yong et al. (2010).

\subsection{Monthly scale discharges}

Figures 12 and 13 display scatter plots of discharges during the period 2000-2007 simulated using WEB-DHM and TOPMODEL against gauge observations at a monthly scale. 

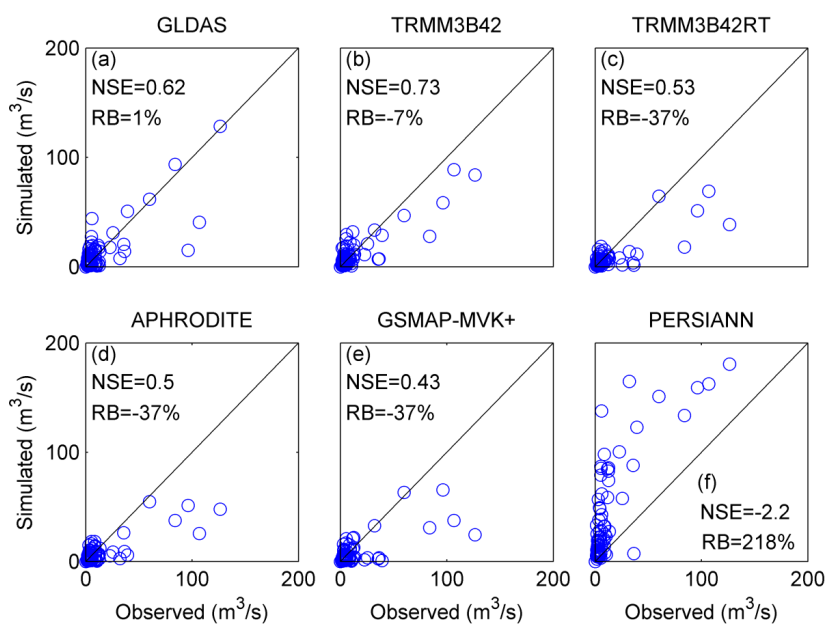

Figure 12. Scatter plots of simulated flows with WEB-DHM against gauge observations at a monthly scale.

In the case of WEB-DHM, the best NSE and RB values are 0.73 and $1 \%$, which correspond with TRMM3B42 and GLDAS respectively. In the case of TOPMODEL, they are 0.58 and $-24 \%$, corresponding with PERSIANN and APHRODITE respectively. The combination of WEB-DHM and TRMM3B42 shows a satisfactory performance, with NSE and RB values of up to 0.73 and $-7 \%$, even though TRMM3B42 is not the best in monthly scale precipitation data evaluation. This reveals the influence of different combinations of hydrological models and precipitation data on discharge simulation, implying that accurate discharge simulation does not solely depend on the accuracy of a precipitation product.

At the monthly scale, although APHRODITE is the best precipitation product and WEB-DHM model has better performance than TOPMODEL in calibration (Fig. 9c and d), the combination of APHRODITE and WEB-DHM is not better in the discharge simulation, which can be shown by comparing Fig. 12d with Fig. 13d (the RB and NSE of WEBDHM and APHRODITE combination are $-37 \%$ and 0.5 , but they are $-24 \%$ and 0.51 for the combination of TOPMODEL and APHRODITE). This could be due to the interactive influence between hydrological models and precipitation products, and implies that the interactions between models and products could be large and have a big influence on discharge simulations. In addition, comparison of Fig. 12d and $b$ shows that discharge simulation of APHRODITE is worse than TRMM3B42, even though APHRODITE is the best precipitation product in terms of all the selected criteria at a monthly scale precipitation amount evaluation. This information shows that better precipitation products do not guarantee better discharge simulations. These results imply that, although the satellite-based precipitation products are not as accurate as gauge-based products in rainfall amount estimation, they could have a better performance in discharge
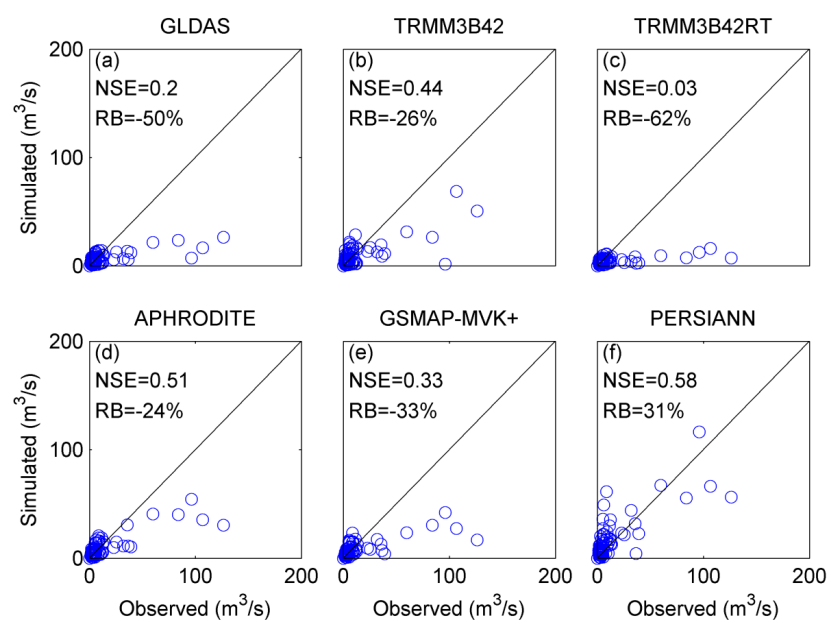

Figure 13. Scatter plots of simulated discharges with TOPMODEL against gauge observations at a monthly scale.

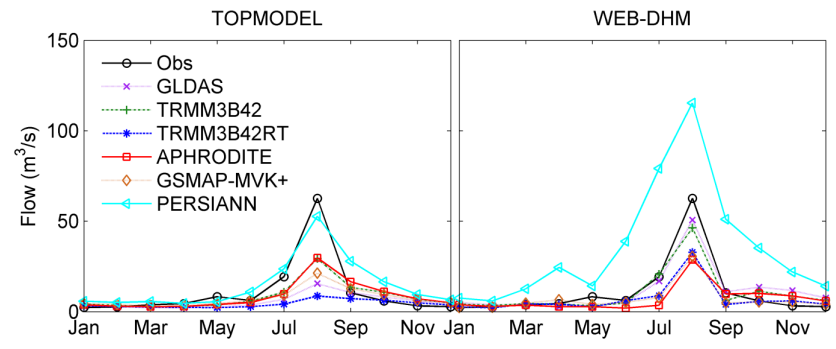

Figure 14. Inter-annual average monthly discharges.

simulations if the combination of precipitation product and hydrological model is good.

\subsection{Inter-annual average monthly discharges}

Figure 14 shows the inter-annual average monthly discharges of all selected precipitation products during the period 20002007. In the case of TOPMODEL, PERSIANN agrees well with gauge observations, and all products underestimate discharges in August. In the case of WEB-DHM, GLDAS data and TRMM3B42 data have a better performance than other data but, with the exception of PERSIANN, all products underestimate peak discharge in August. The simulation results show huge differences even though Fig. 9e and $\mathrm{f}$ show that TOPMODEL and WEB-DHM have almost the same performance using observed data; this is because of the impacts of interactive influence between hydrological models and precipitation products.

\subsection{Uncertainty source quantification}

All above results suggest that discharge simulations are influenced by precipitation products, hydrological models, and interactions between hydrological models and precipitation products. Thus it is essential to quantify the respective influ- 
ence. Figure 15a and $\mathrm{b}$ show contributions of precipitation products, hydrological models, and their interactions to uncertainties in monthly average discharges and different flow quantiles respectively. Figure $15 \mathrm{~b}$ shows quantiles computed at a daily time step. The contributions of uncertainty sources are represented by stripes.

Figure 15a shows that precipitation data contribute most of the uncertainty in discharges, and contribute more than hydrological models. Interactions between hydrological models and precipitation products have large contributions, at a similar level to those from hydrological models. In summer (July to September), the contribution of precipitation data is less than most other months except March. However, the uncertainty in precipitation intensity increases in summer (recall the results in Sect. 3.2). In non-summer months except March, the uncertainty contribution from precipitation products is larger than in summer. These differences maybe result from the non-linear propagation of uncertainty through hydrological models. In March, the contribution of hydrological models is larger than in other months, which may result from the decrease in influences of interactions and precipitation products, and from the non-linear influence of the hydrological models.

Figure $15 \mathrm{~b}$ shows that, for small discharges (smaller than $25 \%$ quantile which corresponds to an observed discharge value of $1.79 \mathrm{~m}^{3} \mathrm{~s}^{-1}$ ) and large discharges (larger than $99 \%$ quantile which corresponds to an observed discharge value of $157 \mathrm{~m}^{3} \mathrm{~s}^{-1}$ ), hydrological models contribute most of the uncertainties. For middle-magnitude flows (between 25 and $99 \%$ quantiles), precipitation products contribute the majority, and the contribution of interactions is not negligible and of similar magnitude to the contribution from hydrological models. The contribution of interactions is larger for middle-magnitude flows than for small and large discharges. The different contributions of interactions for various magnitude flows may be because different magnitude rainfall data could trigger different hydrological processes (Herman et al., 2013). Small discharges mainly come from base flows which are relatively stable and do not need much rainfall to be triggered, and large discharges are mainly controlled by overland flows when heavy precipitation occurs. Middle-magnitude discharges consist of contributions from base flows, lateral subsurface flows, and overland flows, and can be triggered by rainfalls of various magnitudes - thus interactions are more variable.

Although heavy rainfall data have high uncertainty (recall the results in Sect. 3.1), precipitation products have a small contribution to uncertainty in large discharges (Fig. 15b). This implies that the uncertainty in high precipitation is compensated by the high non-linearity in hydrological models.

In this study, because hydrological model parameters were calibrated using gauge observations, the hydrological model parameter uncertainty was not considered. Although the uncertainty contribution results in this study may not be transferable to other basins, the proposed framework provides a
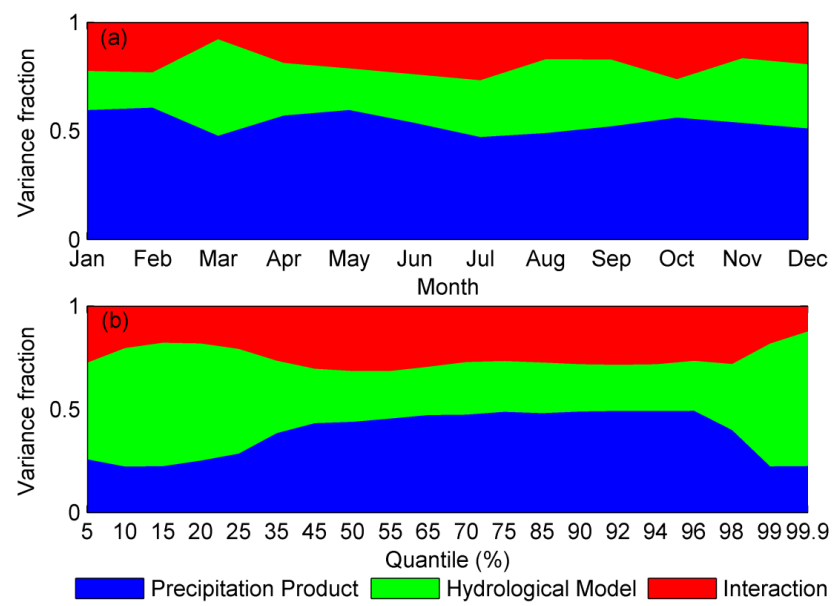

Figure 15. Contributions of uncertainty sources to (a) average monthly discharges and (b) discharge quantiles based on daily-scale simulated results.

useful tool for quantifying uncertainty contributions in discharge simulations using precipitation products.

\section{Discussion}

The spatial variations in precipitation are not considered in this study. The study region is a small river basin, as shown in Fig. 1; there are only 11 grids inside the basin boundary for the precipitation products with a spatial resolution of $0.25^{\circ}$. Within a grid of $0.25^{\circ}$, there are no differences in precipitation amount between the $300 \mathrm{~m} \times 300 \mathrm{~m}$ grids used in hydrological models, and differences exist at the level of $0.25^{\circ}$ grids only. Sapriza-Azuri et al. (2015) suggested that the spatial variability of precipitation has little influence on rapidly responding river discharges; this is the case in this study basin because the flow transport time from the most upper part of the basin to the downstream discharge gauge is $6 \mathrm{~h}$, which is shorter than the daily and monthly time steps of discharges investigated. Therefore, the spatial distributions of precipitation products with a resolution of $0.25^{\circ}$ in the relatively small river basin have little influence on the simulated discharges. However, the assumption of uniform distribution can be regarded as another uncertainty source against spatial variability, and its influence can be assessed using the proposed uncertainty quantification framework. This will allow us to compare the relative contributions of the assumption to those from other sources such as hydrological models, which will be investigated using a much larger river basin in future work.

In addition to improving the accuracy of precipitation products, a good coalition could help to achieve the performance in discharge simulations. Our approach provides a way to assess the different coalitions, i.e. the overall uncertainties in simulated discharges from different combinations 
of hydrological models and precipitation products. More precipitation products and hydrological models should be included and tested in future work.

It should be noted that other input data including temperature, downward solar radiation, long-wave radiation, air pressure, wind speed, and humidity may also have uncertainties. However, Fig. 9 shows that the simulated discharge data are acceptable, particularly at monthly and inter-annual scales using these data. Research has shown that the land surface temperatures are highly accurate compared with MODIS satellite land surface temperature observations (Wang et al., 2011; Qi et al., 2015). Thus, the uncertainties from the other inputs are not considered in our case study river basin.

In this study, the parameter values calibrated using gauge observations are not tuned to a specific product. That is, there is little compensation by model parameters for the errors in input precipitation data. The differences in modelling accuracy mainly result from the different representations of hydrological processes. That is, the errors in precipitation products are primarily compensated by the different representations of model processes.

\section{Summary and conclusions}

This research assesses the applicability of six precipitation products with fine spatial and temporal resolutions at a high-latitude region in northeast China, using both statistical and hydrological evaluation methods at multitemporal scales. A framework is proposed to quantify uncertainty contributions of precipitation products, hydrological models, and their interactions to simulated discharges. These products are TRMM version 7 products (TRMM3B42 and TRMM3B42RT), GLDAS, APHRODITE, PERSIANN, and GSMAP-MVK + . The fully distributed WEB-DHM and semi-distributed TOPMODEL were employed to investigate the influence of hydrological models on simulated discharges. The results show the uncertainty characteristics of the six products, and reveal strategies that could improve precipitation products. This information could provide references for future precipitation product development. The proposed framework can reveal hydrological simulation uncertainties using precipitation products; thus it provides useful information on precipitation product applications. The following conclusions are presented on the basis of this study.

First, at a daily scale, selecting the best precipitation products is very difficult, while, at a monthly scale, APHRODITE has the best performance in terms of NSE, RB, RMSE, and $\mathrm{CC}$, and also retains a high probability of detection and critical success index. This information implies that the APHRODITE algorithm is effective, and APHRODITE could be a very good data set to refine and validate satellitebased precipitation products.

Second, GSMAP-MVK + shows a huge advantage, and is better than TRMM3B42 in RB, NSE, RMSE, CC, false alarm ratio, and critical success index, while PERSIANN is better than TRMM3B42 in probability of detection and precipitation probability distribution estimation. At present, the NASA Global Precipitation Measurement (GPM) mission combines the artificial neural network function of PERSIANN and precipitation radar-matching of TRMM Multisatellite Precipitation Analysis. However, the above finding implies that incorporating the GSMAP-MVK+ estimation approach into GPM could be useful as well.

Third, it is found that, although high uncertainty exists in heavy rainfall, hydrological models contribute mostly to the uncertainty in extreme discharges. This may result from the non-linear propagation of uncertainty through hydrological models, and implies that high uncertainties in extreme rainfall do not mean high uncertainties in extreme discharges.

Fourth, interactions between hydrological models and precipitation products contribute a lot to uncertainty in discharge simulations, and interactive impacts are influenced by discharge magnitude. Because of interactive effects, for hydrological models with similar performances in calibration, using the same precipitation products for discharge simulations does not provide a similar level of accuracy in discharge simulations, and in fact very different predictions could be obtained. In addition, this finding implies that only considering precipitation products or hydrological model uncertainties could result in overestimation of precipitation product contribution and hydrological model contribution to discharge uncertainty.

Fifth, a good discharge simulation depends on a good coalition of a hydrological model and a precipitation product, and a better precipitation product does not necessarily guarantee a better discharge simulation. This suggests that, although the satellite-based precipitation products are not as accurate as the gauge-based product, they could have better performance in discharge simulations when appropriately combined with hydrological models. It should be noted that this finding should be further tested with more river basins, in particular large river basins accounting for spatial variability in precipitation products.

In the future, calculating deterministic discharge simulations considering precipitation product uncertainties and hydrological model uncertainties should be studied because the above results show that product uncertainties and model uncertainties all are important. In addition, recalibrating hydrological models using precipitation products may reduce the interactive influence between hydrological models and precipitation products on simulated discharges, and this may explain why recalibration can improve discharge simulation accuracy. This should be verified in future work. Further, future research is encouraged to incorporate the GSMAP-MVK+ estimation approach into GPM because of the good performance of GSMAP-MVK+. 
Acknowledgements. This study was supported by the National Natural Science Foundation of China (grant no. 51320105010 and 51279021). The first author gratefully acknowledges the financial support provided by the China Scholarship Council. The APHRODITE data were downloaded from http://www.chikyu.ac.jp/precip/pro-ducts/index.html. The TRMM 3B42 data were downloaded from http: //mirador.gsfc.nasa.gov/cgi-bin/mirador/presentNavigation. $\mathrm{pl}$ ?tree=project $\&$ project $=\mathrm{TRMM} \&$ dataGroup $=$ Gridded .

TRMM 3B40RT data were downloaded from ftp://trmmopen. nascom.nasa.gov/pub/merged/combinedMicro/. TRMM 3B41RT data were downloaded from ftp://trmmopen.nascom.nasa.gov/pub/ merged/calibratedIR/. TRMM3B42RT data were downloaded from ftp://trmmopen.nascom.nasa.gov/pub/merged/mergeIRMicro/.

PERSIANN data were downloaded from http://chrs.web.uci.edu/ persiann/data.html. GSMAP_MVK data were downloaded from http://sharaku.eorc.jaxa.jp/GSMaP_crest/. The GLDAS data were downloaded from http://mirador.gsfc.nasa.gov/cgi-bin/mirador/ homepageAlt.pl?keyword=GLDAS_NOAH025SUBP_3H. The data of Biliu basin were obtained from the Biliu reservoir administration.

Edited by: B. Su

\section{References}

Aonashi, K., Awaka, J., Hirose, M., Kozu, T., Kubota, T., Liu, G., Shige, S., Kida, S., Seto, S., Takahashi, N., and Takayabu, Y. N.: GSMaP Passive Microwave Precipitation Retrieval Algorithm: Algorithm Description and Validation, J. Meteorol. Soc. Jpn., 87A, 119-136, doi:10.2151/jmsj.87A.119, 2009.

Artan, G., Gadain, H., Smith, J. L., Asante, K., Bandaragoda, C. J., and Verdin, J. P.: Adequacy of satellite derived rainfall data for stream flow modeling, Nat. Hazards, 43, 167-185, doi:10.1007/s11069-007-9121-6, 2007.

Asadullah, A., McIntyre, N., and Kigobe, M. A. X.: Evaluation of five satellite products for estimation of rainfall over Uganda, Hydrolog. Sci. J., 53, 1137-1150, doi:10.1623/hysj.53.6.1137, 2008.

Bastola, S., Ishidaira, H., and Takeuchi, K.: Regionalisation of hydrological model parameters under parameter uncertainty: A case study involving TOPMODEL and basins across the globe, J. Hydrol., 357, 188-206, doi:10.1016/j.jhydrol.2008.05.007, 2008.

Betts, A. K., Chen, F., Mitchell, K. E., and Janjic, Z. I.: Assessment of the land surface and boundary layer models in two operational versions of the NCEP Eta Model using FIFE data, Mon. Weather Rev., 125, 2896-2916, doi:10.1175/15200493(1997)125<2896:aotlsa>2.0.co;2, 1997.

Beven, K. J. and Binley, A.: The future of distributed models model calibration and uncertainty prediction, Hydrol. Process., 6, 279-298, doi:10.1002/hyp.3360060305, 1992.

Beven, K. J. and Freer, J. E.: A dynamic TOPMODEL, Hydrol. Process., 15, 1993-2011, doi:10.1002/hyp.252, 2001a.

Beven, K. J. and Freer, J. E.: Equifinality, data assimilation, and uncertainty estimation in mechanistic modelling of complex environmental systems using the GLUE methodology, J. Hydrol., 249, 11-29, doi:10.1016/S0022-1694(01)00421-8, 2001 b.
Beven, K. J. and Kirkby, M. J.: A physically based, variable contributing area model of basin hydrology, Hydrolog. Sci. Bull., 24, 43-69, doi:10.1080/02626667909491834, 1979.

Blasone, R.-S., Vrugt, J. A., Madsen, H., Rosbjerg, D., Robinson, B. A., and Zyvoloski, G. A.: Generalized likelihood uncertainty estimation (GLUE) using adaptive Markov Chain Monte Carlo sampling, Adv. Water Resour., 31, 630-648, doi:10.1016/j.advwatres.2007.12.003, 2008.

Blazkova, S. and Beven, K.: Flood frequency prediction for data limited catchments in the Czech Republic using a stochastic rainfall model and TOPMODEL, J. Hydrol., 195, 256-278, doi:10.1016/S0022-1694(96)03238-6, 1997.

Bosshard, T., Carambia, M., Goergen, K., Kotlarski, S., Krahe, P., Zappa, M., and Schär, C.: Quantifying uncertainty sources in an ensemble of hydrological climate-impact projections, Water Resour. Res., 49, 1523-1536, doi:10.1029/2011wr011533, 2013.

Bouilloud, L., Chancibault, K., Vincendon, B., Ducrocq, V., Habets, F., Saulnier, G.-M., Anquetin, S., Martin, E., and Noilhan, J.: Coupling the ISBA Land Surface Model and the TOPMODEL Hydrological Model for Mediterranean Flash-Flood Forecasting: Description, Calibration, and Validation, J. Hydrometeorol., 11, 315-333, doi:10.1175/2009jhm1163.1, 2010.

Buarque, D. C., de Paiva, R. C. D., Clarke, R. T., and Mendes, C. A. B.: A comparison of Amazon rainfall characteristics derived from TRMM, CMORPH and the Brazilian national rain gauge network, J. Geophys. Res., 116, D19105, doi:10.1029/2011jd016060, 2011.

Cameron, D. S., Beven, K. J., Tawn, J., Blazkova, S., and Naden, P.: Flood frequency estimation by continuous simulation for a gauged upland catchment (with uncertainty), J. Hydrol., 219, 169-187, doi:10.1016/S0022-1694(99)00057-8, 1999.

Chen, F., Mitchell, K., Schaake, J., Xue, Y., Pan, H.-L., Koren, V., Duan, Q. Y., Ek, M., and Betts, A.: Modeling of land surface evaporation by four schemes and comparison with FIFE observations, J. Geophys. Res., 101, 7251, doi:10.1029/95jd02165, 1996.

Chen, S., Hong, Y., Cao, Q., Gourley, J. J., Kirstetter, P.-E., Yong, B., Tian, Y., Zhang, Z., Shen, Y., Hu, J., and Hardy, J.: Similarity and difference of the two successive V6 and V7 TRMM multisatellite precipitation analysis performance over China, J. Geophys. Res.-Atmos., 118, 13060-13074, doi:10.1002/2013jd019964, 2013a.

Chen, S., Hong, Y., Gourley, J. J., Huffman, G. J., Tian, Y., Cao, Q., Yong, B., Kirstetter, P.-E., Hu, J., Hardy, J., Li, Z., Khan, S. I., and Xue, X.: Evaluation of the successive V6 and V7 TRMM multisatellite precipitation analysis over the Continental United States, Water Resour. Res., 49, 8174-8186, doi:10.1002/2012wr012795, 2013b.

Dai, Y., Zeng, X., Dickinson, R. E., Baker, I., Bonan, G. B., Bosilovich, M. G., Denning, A. S., Dirmeyer, P. A., Houser, P. R., Niu, G., Oleson, K. W., Schlosser, C. A., and Yang, Z.-L.: The Common Land Model, B. Am. Meteorol. Soc., 84, 10131023, doi:10.1175/bams-84-8-1013, 2003.

Dinku, T., Connor, S. J., Ceccato, P., and Ropelewski, C. F.: Comparison of global gridded precipitation products over a mountainous region of Africa, Int. J. Climatol., 28, 1627-1638, doi:10.1002/joc.1669, 2008.

Ebert, E. E., Janowiak, J. E., and Kidd, C.: Comparison of NearReal-Time Precipitation Estimates from Satellite Observations 
and Numerical Models, B. Am. Meteorol. Soc., 88, 47-64, doi:10.1175/bams-88-1-47, 2007.

Ek, M. B.: Implementation of Noah land surface model advances in the National Centers for Environmental Prediction operational mesoscale Eta model, J. Geophys. Res., 108, 8851, doi:10.1029/2002jd003296, 2003.

FAO - Food and Agriculture Association: Digital soil map of the world and derived soil properties, land and water digital media series, CD-ROM, Rome, Italy, 2003.

Freer, J. E., Beven, K. J., and Ambroise, B.: Bayesian Estimation of Uncertainty in Runoff Prediction and the Value of Data: An Application of the GLUE Approach, Water Resour. Res., 32, 21612173, doi:10.1029/95wr03723, 1996.

Gallart, F., Latron, J., Llorens, P., and Beven, K. J.: Upscaling discrete internal observations for obtaining catchmentaveraged TOPMODEL parameters in a small Mediterranean mountain basin, Phys. Chem. Earth, 33, 1090-1094, doi:10.1016/j.pce.2008.03.003, 2008.

Gao, Y. C. and Liu, M. F.: Evaluation of high-resolution satellite precipitation products using rain gauge observations over the Tibetan Plateau, Hydrol. Earth Syst. Sci., 17, 837-849, doi:10.5194/hess-17-837-2013, 2013.

Heidari, A., Saghafian, B., and Maknoon, R.: Assessment of flood forecasting lead time based on generalized likelihood uncertainty estimation approach, Stoch. Environ. Res. Risk A., 20, 363-380, doi:10.1007/s00477-006-0032-y, 2006.

Herman, J. D., Reed, P. M., and Wagener, T.: Time-varying sensitivity analysis clarifies the effects of watershed model formulation on model behavior, Water Resour. Res., 49, 1400-1414, doi:10.1002/wrcr.20124, 2013.

Hong, Y., Hsu, K.-L., Moradkhani, H., and Sorooshian, S.: Uncertainty quantification of satellite precipitation estimation and Monte Carlo assessment of the error propagation into hydrologic response, Water Resour. Res., 42, W08421, doi:10.1029/2005wr004398, 2006.

Hossain, F. and Anagnostou, E. N.: Assessment of a stochastic interpolation based parameter sampling scheme for efficient uncertainty analyses of hydrologic models, Comput. Geosci., 31, 497-512, doi:10.1016/j.cageo.2004.11.001, 2005.

Huffman, G. J., Bolvin, D. T., Nelkin, E. J., Wolff, D. B., Adler, R. F., Gu, G., Hong, Y., Bowman, K. P., and Stocker, E. F.: The TRMM Multisatellite Precipitation Analysis (TMPA): QuasiGlobal, Multiyear, Combined-Sensor Precipitation Estimates at Fine Scales, J. Hydrometeorol., 8, 38-55, doi:10.1175/jhm560.1, 2007.

Jiang, S., Ren, L., Hong, Y., Yong, B., Yang, X., Yuan, F., and Ma, M.: Comprehensive evaluation of multi-satellite precipitation products with a dense rain gauge network and optimally merging their simulated hydrological flows using the Bayesian model averaging method, J. Hydrol., 452-453, 213225, doi:10.1016/j.jhydrol.2012.05.055, 2012.

Kato, H., Rodell, M., Beyrich, F., Cleugh, H., Gorsel, E. V., Liu, H., and Meyers, T. P.: Sensitivity of Land Surface Simulations to Model Physics, Land Characteristics, and Forcings, at Four CEOP Sites, J. Meteorol. Soc. Jpn., 85A, 187-204, doi:10.2151/jmsj.85A.187, 2007.

Kneis, D., Chatterjee, C., and Singh, R.: Evaluation of TRMM rainfall estimates over a large Indian river basin (Mahanadi), Hy- drol. Earth Syst. Sci., 18, 2493-2502, doi:10.5194/hess-18-24932014, 2014.

Koren, V., Schaake, J., Mitchell, K., Duan, Q. Y., Chen, F., and Baker, J. M.: A parameterization of snowpack and frozen ground intended for NCEP weather and climate models, J. Geophys. Res., 104, 19569, doi:10.1029/1999jd900232, 1999.

Koster, R. D. and Suarez, M. J.: Modeling the land surface boundary in climate models as a composite of independent vegetation stands, J. Geophys. Res.-Atmos., 97, 2697-2715, doi:10.1029/91JD01696, 1992.

Kubota, T., Shige, S., Hashizurne, H., Aonashi, K., Takahashi, N., Seto, S., Hirose, M., Takayabu, Y. N., Ushio, T., Nakagawa, K., Wanami, K., Kachi, M., and Okamoto, K.: Global precipitation map using satellite-borne microwave radiometers by the GSMaP project: Production and validation, IEEE T. Geosci. Remote, 45, 2259-2275, doi:10.1109/tgrs.2007.895337, 2007.

Kuczera, G. and Parent, E.: Monte Carlo assessment of parameter uncertainty in conceptual catchment models- the Metropolis algorithm, J. Hydrol., 211, 69-85, doi:10.1016/S00221694(98)00198-X, 1998.

Kuczera, G., Kavetski, D., Franks, S., and Thyer, M.: Towards a Bayesian total error analysis of conceptual rainfall-runoff models: Characterising model error using storm-dependent parameters, J. Hydrol., 331, 161-177, doi:10.1016/j.jhydrol.2006.05.010, 2006.

Kummerow, C., Simpson, J., and Thiele, O.: The status of the Tropical Rainfall Measuring Mission (TRMM) after two years in orbit, J. Appl. Meteorol. Clim., 39, 1965-1982, doi:10.1175/15200450(2001)040<1965:TSOTTR>2.0.CO;2, 2000.

Li, Z., Yang, D., and Hong, Y.: Multi-scale evaluation of high-resolution multi-sensor blended global precipitation products over the Yangtze River, J. Hydrol., 500, 157-169, doi:10.1016/j.jhydrol.2013.07.023, 2013.

Liang, X., Lettenmaier, D. P., Wood, E. F., and Burges, S. J.: A simple hydrologically based model of land-surface water and energy fluxes for general-circulation models, J. Geophys. Res.-Atmos., 99, 14415-14428, doi:10.1029/94jd00483, 1994.

Maggioni, V., Vergara, H. J., Anagnostou, E. N., Gourley, J. J., Hong, Y., and Stampoulis, D.: Investigating the Applicability of Error Correction Ensembles of Satellite Rainfall Products in River Flow Simulations, J. Hydrometeorol., 14, 1194-1211, doi:10.1175/jhm-d-12-074.1, 2013.

Meng, J., Li, L., Hao, Z., Wang, J., and Shao, Q.: Suitability of TRMM satellite rainfall in driving a distributed hydrological model in the source region of Yellow River, J. Hydrol., 509, 320332, doi:10.1016/j.jhydrol.2013.11.049, 2014.

Müller, M. F. and Thompson, S. E.: Bias adjustment of satellite rainfall data through stochastic modeling: Methods development and application to Nepal, Adv. Water Resour., 60, 121-134, doi:10.1016/j.advwatres.2013.08.004, 2013.

Nikolopoulos, E. I., Anagnostou, E. N., Hossain, F., Gebremichael, M., and Borga, M.: Understanding the Scale Relationships of Uncertainty Propagation of Satellite Rainfall through a Distributed Hydrologic Model, J. Hydrometeorol., 11, 520-532, doi:10.1175/2009jhm1169.1, 2010.

Ochoa, A., Pineda, L., Crespo, P., and Willems, P.: Evaluation of TRMM 3B42 precipitation estimates and WRF retrospective precipitation simulation over the Pacific-Andean region of 
Ecuador and Peru, Hydrol. Earth Syst. Sci., 18, 3179-3193, doi:10.5194/hess-18-3179-2014, 2014.

Pan, M., Li, H., and Wood, E.: Assessing the skill of satellite-based precipitation estimates in hydrologic applications, Water Resour. Res., 46, W09535, doi:10.1029/2009wr008290, 2010.

Parton, W. J. and Logan, J. A.: A model for diurnal variation in soil and air temperature, Agricult. Meteorol., 23, 205-216, doi:10.1016/0002-1571(81)90105-9, 1981.

Peng, Z., Wang, Q. J., Bennett, J. C., Pokhrel, P., and Wang, Z.: Seasonal precipitation forecasts over China using monthly largescale oceanic-atmospheric indices, J. Hydrol., 519, 792-802, doi:10.1016/j.jhydrol.2014.08.012, 2014a.

Peng, Z., Wang, Q. J., Bennett, J. C., Schepen, A., Pappenberger, F., Pokhrel, P., and Wang, Z.: Statistical calibration and bridging of ECMWF System4 outputs for forecasting seasonal precipitation over China, J. Geophys. Res.-Atmos., 119, 7116-7135, doi:10.1002/2013jd021162, 2014b.

Peters, N. E., Freer, J., and Beven, K.: Modelling hydrologic responses in a small forested catchment (Panola Mountain, Georgia, USA): a comparison of the original and a new dynamic TOPMODEL, Hydrol. Process., 17, 345-362, doi:10.1002/hyp.1128, 2003

Qi, W., Zhang, C., Chu, J., and Zhou, H.: Sobol"s sensitivity analysis for TOPMODEL hydrological model: A case study for the Biliu River Basin, China, J. Hydrol. Environ. Res., 1, 1-10, 2013.

Qi, W., Zhang, C., Fu, G., and Zhou, H.: Global Land Data Assimilation System data assessment using a distributed biosphere hydrological model, J. Hydrol., 528, 652-667, doi:10.1016/j.jhydrol.2015.07.011, 2015.

Qi, W., Zhang, C., Fu, G., and Zhou, H.: Quantifying dynamic sensitivity of optimization algorithm parameters to improve hydrological model calibration, J. Hydrol., 533, 213-223, doi:10.1016/j.jhydrol.2015.11.052, 2016.

Rodell, M., Houser, P. R., Jambor, U., Gottschalck, J., Mitchell, K., Meng, C. J., Arsenault, K., Cosgrove, B., Radakovich, J., Bosilovich, M., Entin, J. K., Walker, J. P., Lohmann, D., and Toll, D.: The Global Land Data Assimilation System, B. Am. Meteorol. Soc., 85, 381-394, doi:10.1175/bams-85-3-381, 2004.

Sapriza-Azuri, G., Jódar, J., Navarro, V., Slooten, L. J., Carrera, J., and Gupta, H. V.: Impacts of rainfall spatial variability on hydrogeological response, Water Resour. Res., 51, 1300-1314, doi:10.1002/2014wr016168, 2015.

Sellers, P. J.: Modeling the Exchanges of Energy, Water, and Carbon Between Continents and the Atmosphere, Science, 275, 502509, doi:10.1126/science.275.5299.502, 1997.

Sellers, P. J., Mintz, Y., Sud, Y. C., and Dalcher, A.: A Simple Biosphere Model (SIB) for Use within General Circulation Models, J. Atmos. Sci., 43, 505-531, doi:10.1175/15200469(1986)043<0505:ASBMFU>2.0.CO;2, 1986.

Sellers, P. J., Randall, D. A., Collatz, G. J., Berry, J. A., Field, C. B., Dazlich, D. A., Zhang, C., Collelo, G. D., and Bounoua, L.: A Revised Land Surface Parameterization (SiB2) for Atmospheric GCMS. Part I: Model Formulation, J. Climate, 9, 676-705, doi:10.1175/1520-0442(1996)009< 0676:ARLSPF>2.0.CO;2, 1996.

Serpetzoglou, E., Anagnostou, E. N., Papadopoulos, A., Nikolopoulos, E. I., and Maggioni, V.: Error Propagation of Remote Sensing Rainfall Estimates in Soil Moisture Prediction from a Land Surface Model, J. Hydrometeorol., 11, 705-720, doi:10.1175/2009jhm1166.1, 2010.

Shou, Y. and $\mathrm{Xu}, \mathrm{J} .:$ The rainstorm and mesoscale convective systems over northeast China in june 2005 I: A synthetic analysis of mcs by conventional observations and satellite data, Acta Meteorol. Sin., 65, 160-170, 2007a.

Shou, Y. and $\mathrm{Xu}, \mathrm{J} .:$ The rainstorm and mesoscale convective systems over northeast China in june 2005 II: A synthetic analysis of mcs's dynamical structure by radar and satellite observations, Acta Meteorol. Sin., 65, 171-182, 2007b.

Shrestha, M., Wang, L., Koike, T., Tsutsui, H., Xue, Y., and Hirabayashi, Y.: Correcting basin-scale snowfall in a mountainous basin using a distributed snowmelt model and remote-sensing data, Hydrol. Earth Syst. Sci., 18, 747-761, doi:10.5194/hess-18-747-2014, 2014.

Sorooshian, S., Gao, X., Hsu, K., Maddox, R. A., Hong, Y., Gupta, H. V., and Imam, B.: Diurnal Variability of Tropical Rainfall Retrieved from Combined GOES and TRMM Satellite Information, J. Climate, 15, 983-1001, doi:10.1175/15200442(2002)015<0983:DVOTRR>2.0.CO;2, 2002.

Sorooshian, S., Hsu, K. L., Gao, X., Gupta, H. V., Imam, B., and Braithwaite, D.: Evaluation of PERSIANN system satellite-based estimates of tropical rainfall, B. Am. Meteorol. Soc., 81, 2035-2046, doi:10.1175/15200477(2000)081<2035:eopsse>2.3.co;2, 2000.

Sorooshian, S., Lawford, R. G., Try, P., Rossow, W., Roads, J., Polcher, J., Sommeria, G., and Schifer, R.: Water and energy cycles: Investigating the links, WMO Bull., 54, 58-64, 2005.

Su, F., Hong, Y., and Lettenmaier, D. P.: Evaluation of TRMM Multisatellite Precipitation Analysis (TMPA) and Its Utility in Hydrologic Prediction in the La Plata Basin, J. Hydrometeorol., 9, 622-640, doi:10.1175/2007jhm944.1, 2008.

Tapiador, F. J., Turk, F. J., Petersen, W., Hou, A. Y., García-Ortega, E., Machado, L. A. T., Angelis, C. F., Salio, P., Kidd, C., Huffman, G. J., and de Castro, M.: Global precipitation measurement: Methods, datasets and applications, Atmos. Res., 104-105, 7097, doi:10.1016/j.atmosres.2011.10.021, 2012.

Tolson, B. A. and Shoemaker, C. A.: Dynamically dimensioned search algorithm for computationally efficient watershed model calibration, Water Resour. Res., 43, W01413, doi:10.1029/2005wr004723, 2007.

Vrugt, J. A., ter Braak, C. J. F., Gupta, H. V., and Robinson, B. A.: Equifinality of formal (DREAM) and informal (GLUE) Bayesian approaches in hydrologic modeling?, Stoch. Environ. Res. Risk A., 23, 1011-1026, doi:10.1007/s00477-008-0274-y, 2009.

Wang, D., Wang, G., and Anagnostou, E. N.: Use of Satellite-Based Precipitation Observation in Improving the Parameterization of Canopy Hydrological Processes in Land Surface Models, J. Hydrometeorol., 6, 745-763, doi:10.1175/JHM438.1, 2005.

Wang, F., Wang, L., Koike, T., Zhou, H., Yang, K., Wang, A., and Li, W.: Evaluation and application of a fine-resolution global data set in a semiarid mesoscale river basin with a distributed biosphere hydrological model, J. Geophys. Res., 116, D21108, doi:10.1029/2011jd015990, 2011.

Wang, F., Wang, L., Zhou, H., Saavedra Valeriano, O. C., Koike, T., and Li, W.: Ensemble hydrological prediction-based real-time optimization of a multiobjective reservoir during flood season in a semiarid basin with global numerical weather predictions, 
Water Resour. Res., 48, W07520, doi:10.1029/2011wr011366, 2012.

Wang, L., Koike, T., Yang, D. W., and Yang, K.: Improving the hydrology of the Simple Biosphere Model 2 and its evaluation within the framework of a distributed hydrological model, Hydrolog. Sci. J., 54, 989-1006, doi:10.1623/hysj.54.6.989, 2009a.

Wang, L., Koike, T., Yang, K., Jackson, T. J., Bindlish, R., and Yang, D.: Development of a distributed biosphere hydrological model and its evaluation with the Southern Great Plains Experiments (SGP97 and SGP99), J. Geophys. Res., 114, D08107, doi:10.1029/2008jd010800, 2009b.

Wang, L., Koike, T., Yang, K., and Yeh, P. J.-F.: Assessment of a distributed biosphere hydrological model against streamflow and MODIS land surface temperature in the upper Tone River Basin, J. Hydrol., 377, 21-34, doi:10.1016/j.jhydrol.2009.08.005, 2009c.

Wang, L., Koike, T., Yang, K., Jin, R., and Li, H.: Frozen soil parameterization in a distributed biosphere hydrological model, Hydrol. Earth Syst. Sci., 14, 557-571, doi:10.5194/hess-14-5572010, 2010a.

Wang, L., Wang, Z., Koike, T., Yin, H., Yang, D., and He, S.: The assessment of surface water resources for the semi-arid Yongding River Basin from 1956 to 2000 and the impact of land use change, Hydrol. Process., 24, 1123-1132, doi:10.1002/hyp.7566, 2010b.

Xie, P., Chen, M., Yang, S., Yatagai, A., Hayasaka, T., Fukushima, Y., and Liu, C.: A Gauge-Based Analysis of Daily Precipitation over East Asia, J. Hydrometeorol., 8, 607-626, doi:10.1175/jhm583.1, 2007.

Xue, X., Hong, Y., Limaye, A. S., Gourley, J. J., Huffman, G. J., Khan, S. I., Dorji, C., and Chen, S.: Statistical and hydrological evaluation of TRMM-based Multi-satellite Precipitation Analysis over the Wangchu Basin of Bhutan: Are the latest satellite precipitation products $3 \mathrm{~B} 42 \mathrm{~V} 7$ ready for use in ungauged basins?, J. Hydrol., 499, 91-99, doi:10.1016/j.jhydrol.2013.06.042, 2013.

Yang, D.: Distributed hydrological model using hillslope discretization based on catchment area function: development and applications, PHD thesis, University of Tokyo, Tokyo, 1998.

Yang, K., Koike, T., and Ye, B.: Improving estimation of hourly, daily, and monthly solar radiation by importing global data sets, Agr. Forest Meteorol., 137, 43-55, doi:10.1016/j.agrformet.2006.02.001, 2006.
Yatagai, A., Kamiguchi, K., Arakawa, O., Hamada, A., Yasutomi, N., and Kitoh, A.: APHRODITE: Constructing a Long-Term Daily Gridded Precipitation Dataset for Asia Based on a Dense Network of Rain Gauges, B. Am. Meteorol. Soc., 93, 1401-1415, doi:10.1175/bams-d-11-00122.1, 2012.

Yong, B., Ren, L.-L., Hong, Y., Wang, J.-H., Gourley, J. J., Jiang, S.-H., Chen, X., and Wang, W.: Hydrologic evaluation of Multisatellite Precipitation Analysis standard precipitation products in basins beyond its inclined latitude band: A case study in Laohahe basin, China, Water Resour. Res., 46, W07542, doi:10.1029/2009wr008965, 2010.

Yong, B., Hong, Y., Ren, L.-L., Gourley, J. J., Huffman, G. J., Chen, X., Wang, W., and Khan, S. I.: Assessment of evolving TRMM-based multisatellite real-time precipitation estimation methods and their impacts on hydrologic prediction in a high latitude basin, J. Geophys. Res., 117, D09108, doi:10.1029/2011jd017069, 2012.

Yong, B., Chen, B., Gourley, J. J., Ren, L., Hong, Y., Chen, X., Wang, W., Chen, S., and Gong, L.: Intercomparison of the Version-6 and Version-7 TMPA precipitation products over high and low latitudes basins with independent gauge networks: Is the newer version better in both real-time and post-real-time analysis for water resources and hydrologic extremes?, J. Hydrol., 508, 77-87, doi:10.1016/j.jhydrol.2013.10.050, 2014.

Yuan, M., Li, Z., and Zhang, X.: Analysis of a meso scale convective system during a brief torrential rain event in Northeast China, Acta Meteorol. Sin., 68, 125-136, doi:10.11676/qxxb2010.013, 2010.

Zhao, T. and Yatagai, A.: Evaluation of TRMM 3B42 product using a new gauge-based analysis of daily precipitation over China, Int. J. Climatol., 34, 2749-2762, doi:10.1002/joc.3872, 2014.

Zhou, T., Yu, R., Chen, H., Dai, A., and Pan, Y.: Summer Precipitation Frequency, Intensity, and Diurnal Cycle over China: A Comparison of Satellite Data with Rain Gauge Observations, J. Climate, 21, 3997-4010, doi:10.1175/2008jcli2028.1, 2008.

Zhou, X. Y., Zhang, Y. Q., Yang, Y. H., Yang, Y. M., and Han, S. M.: Evaluation of anomalies in GLDAS-1996 dataset, Water Sci. Technol., 67, 1718-1727, doi:10.2166/wst.2013.043, 2013. 